\title{
Karst geology and cave fauna of Austria: a concise review
}

\author{
Erhard Christian ${ }^{1}$ and Christoph Spötl ${ }^{2}$
}

\begin{abstract}
:
Christian E. \& Spötl C. 2010. Karst geology and cave fauna of Austria: a concise review. International Journal of Speleology, 39 (2), $71-90$. Bologna (Italy). ISSN 0392-6672.

The state of cave research in Austria is outlined from the geological and zoological perspective. Geologic sections include the setting of karst regions, tectonic and palaeoclimatic control on karst, modern cave environments, and karst hydrology. A chapter on the development of Austrian biospeleology in the $20^{\text {th }}$ century is followed by a survey of terrestrial underground habitats, biogeographic remarks, and an annotated selection of subterranean invertebrates.
\end{abstract}

Keywords: karst, caves, geospeleology, biospeleology, Austria

Received 8 January 2010; Revised 8 April 2010; Accepted 10 May 2010

\section{INTRODUCTION}

Austria has a long tradition of karst-related research going back to the $19^{\text {th }}$ century, when the presentday country was part of the much larger AustroHungarian Empire. Franz Kraus was among the first worldwide to summarise the existing knowledge in a textbook, Höhlenkunde (Kraus, 1894; reprinted 2009). Speleological activities continue to prosper in Austria and in particular in the Eastern Alps. Austria currently holds the largest cave system of the European Union (Schönberg-Höhlensystem), the highest show cave in Europe (Spannagelhöhle), some of the largest ice caves on this planet (Eisriesenwelt, Dachstein Rieseneishöhle), as well as a number of very deep caves up to $1.6 \mathrm{~km}$ in vertical extent. A total of ca. 15,000 caves are registered in Austria as of 2009.

This article provides a summary of Austrian karst geology and subterranean zoology. The last review of caves was published almost four decades ago (Bauer and Zötl, 1972). Since the publication of a biospeleological summary (Christian et al. 1994) a number of records have accumulated which justify surveying zoological achievements and underground biodiversity.

These days, a comprehensive species list is a matter for internet files rather than print. In the present paper, addressed to a broader audience, we disregard most of the slightly troglophilic species. The focus is laid on invertebrates that exhibit regular and close relationships with the subterranean habitat,

1 Institute of Zoology, University of Natural Resources and Applied Life Sciences, Vienna. Gregor Mendel Str. 33, A-1180 Wien, Austria. erhard.christian@boku.ac.at

2 Institute of Geology and Palaeontology, University of Innsbruck. Innrain 52, A-6020 Innsbruck, Austria. christoph. spoet1@uibk.ac.at be it temporarily in a certain phase of the animal's life cycle (subtroglophiles), permanently in certain populations (eutroglophiles), or permanently across the entire species (troglobionts). An easy task as long as terrestrial metazoans are considered, this undertaking proves intricate with aquatic organisms. We do not know of any Austrian air-breathing species that lives truely subterranean (i.e., not in but below the soil) and has never invaded what we usually call caves or mines. There are, however, many stygophiles and stygobionts which have never been observed in caves, though some of them appear capable of colonising karst waters. Thus we add selected faunal information from recent groundwater studies.

\section{GEOSPELEOLOGY}

The territory of Austria extends $300 \mathrm{~km}$ from north to south and more than $550 \mathrm{~km}$ from east to west $\left(83,855 \mathrm{~km}^{2}\right)$. Within this area there is a wide range of landscapes, from the open plains in the east to the high mountains of the Alps, showing a difference in altitude of almost $3700 \mathrm{~m}$.

From the geological point of view, Austria comprises major portions of the Bohemian Massif and the Eastern Alps and their forelands to the north, east and southeast (for a popular introduction to Austria's geological structure and history see Krenmayr, 2002). Northernmost Austria is part of the southern sector of the Bohemian Massif, composed of crystalline rocks which once formed a Europe-wide mountain range after the Variscan orogeny. The Austrian Alps are the eastern segment of the Alpine arch (often also referred to as the Eastern Alps), a 1200-km-long mountain range that extends from the French Riviera to the Vienna Basin. Three great bands of mountains stretch across much of the country in a west-to-east direction and form the backbone of the Austrian Alps. 
The band of mountains lying across northern Austria is generally limestone, the Northern Calcareous Alps (NCA), while the mountains extending across central and part of southern Austria are formed by crystalline rocks, the Central Alps. A rather narrow band of limestones straddles the southern border of Austria, the Southern Calcareous Alps. The low-lying areas surrounding the Austrian Alps - Molasse Basin, Vienna Basin, Pannonian Basin, Styrian Basin - are depressions filled with packages of marine sediments and sediments eroded from the rising Alps during and subsequent to the Alpine orogeny. The evolution of the Austrian Alps reflects relative movements of the African and the Eurasian continental plates and several small plate fragments which collided to form an orogenic belt. Compressional tectonics started as early as 100 million years ago (Middle Cretaceous), closing a seaway of several hundred kilometers in width, and thrusting large packages of rocks on top of each other (Pfiffner, 2009). Deformation continued until about 30 million years ago (Oligocene), when the major phase of uplift started in the western part of the Austrian Alps. Since that time this part of the Alps has been continuously exposed to erosion and weathering, part of which is karstification.

About one fifth of Austria consists of rocks susceptible to karstification (Kralik, 2001) and shows karst features including caves, which are primarily bound to the presence of soluble rocks (limestone, locally dolomite, marble; rarely also gypsum). These areas include the NCA (which represent approximately $80 \%$ of Austria's karst areas), parts of the Helvetic nappes in the province of Vorarlberg, metamorphic carbonates scattered throughout the Central Alps including the Grazer Bergland (a karst province also known as Central Styrian Karst), and to a lesser extent also the Southern Calcareous Alps and Southern Alps (Karawanken, Drau Range and parts of the Carnic Alps; Fig. 1).

\section{Geologic setting of karst regions}

Large karst systems in Austria are bound to the occurrence of rather pure limestone (or calcitic marble), less commonly dolomite, and locally also evaporites (gypsum and anhydrite). Argillaceous rocks underlying or tectonically separating these soluble rocks act(ed) as aquicludes and provided stratigraphic (or tectonic) controls on the distribution of the karst networks. The large caves in the Grazer Bergland, for example, developed in low-grade metamorphic platform carbonates of Devonian age (Schöckl Limestone) and rarely cut into the underlying slates of the Arzberg Formation (Behrens et al., 1992). In the NCA, caves abound in the Upper Triassic Dachstein Formation, a rather pure and regularly bedded limestone up to $1.5 \mathrm{~km}$ in thickness. This unit forms morphologically distinct and isolated plateaus in the central part of the NCA, including the name-giving Dachstein, Totes Gebirge, and Tennengebirge. Austria's twelve longest caves including the Schönberg-Höhlensystem (121 $\mathrm{km})$ and Hirlatzhöhle $(96 \mathrm{~km})$ as well as the nine deepest caves including Lamprechtsofen $(1,632 \mathrm{~m})$ are cut in Dachstein Limestone (Pfarr et al., 2007). The second most important karst host rock is the Wetterstein Limestone (Middle to Early Upper Triassic). Examples include the Hochschwab and Rax massifs (NCA), as well as Obir and Villacher Alpe in the Southern Calcareous Alps.

In the Central Alps, carbonate rocks are present as marbles intercalated with schists and gneisses, as carbonate-bearing schists, and as low-grade metamorphic limestones and dolomites on top of the crystalline basement. Because of the greater altitude many known cave systems in the Central Alps are presently located near (currently retreating) glaciers. Examples include the area near Kitzsteinhorn (Kaprun Valley), where caves developed in steeply dipping beds of calcareous schists (Bündner schists) sandwiched between impermeable mica schists (Audra, 2004). This type of confined karst development is also referred to as stripe karst (Lauritzen, 2001). A comparable situation exists at the Hintertux Glacier (Tux Valley, Tyrol), where a 20-m-thick slab of heavily karstified calcite marble is sandwiched between gently to steeply dipping gneiss (Spötl et al., 2004; Fig. 2).

Rather little is known about caves in Austria that formed due to the action of hydrothermal water (see Plan et al., 2009 for a concise review). Although there are a number of thermal springs in different geologic settings (Zötl \& Goldbrunner, 1993), the role of ascending warm palaeowaters in subsurface dissolution remains elusive. A hydroelectric power plant tunnel in the Salzach Valley near Lend, for instance, was flooded by warm water which circulated in karst channels up to several meters in diameter (Horninger, 1959; Spötl et al., 2009). Evidence of hydrothermal water related to karst can also be found along the margins of the southern Vienna Basin (Plan et al., 2006).

A final type of karst, hypogen karst related to hydrocarbon oxidation in conjunction with sulfatesulfide reactions, was only identified at one site, Kraushöhle in Gams (Styria). There, thick deposits of gypsum showing a characteristic sulphur isotopic composition are present in conspicuously wellrounded cave chambers (Puchelt \& Blum, 1989) which were produced by sulphuric acid reacting with the carbonate host rock (De Waele et al., 2009), comparable to the famous Carlsbad Caverns in New Mexico, USA (Hill, 1990).

\section{Tectonic control on karst}

The Wetterstein Limestone is one of the most important rock builders in the western NCA, but the density of long, horizontal caves is conspicuously lower than in the central and eastern NCA. This decrease in cave abundance along an east-west gradient across the NCA has been attributed to tectonics, which gave rise to differential uplift within the NCA (Frisch et al., 2000, 2001). The western part including the provinces of Tyrol and Vorarlberg experienced strong and rather continuous uplift since about 30 million years ago (Late Oligocene) and remained a high mountain range since then. In contrast to this western part, the 


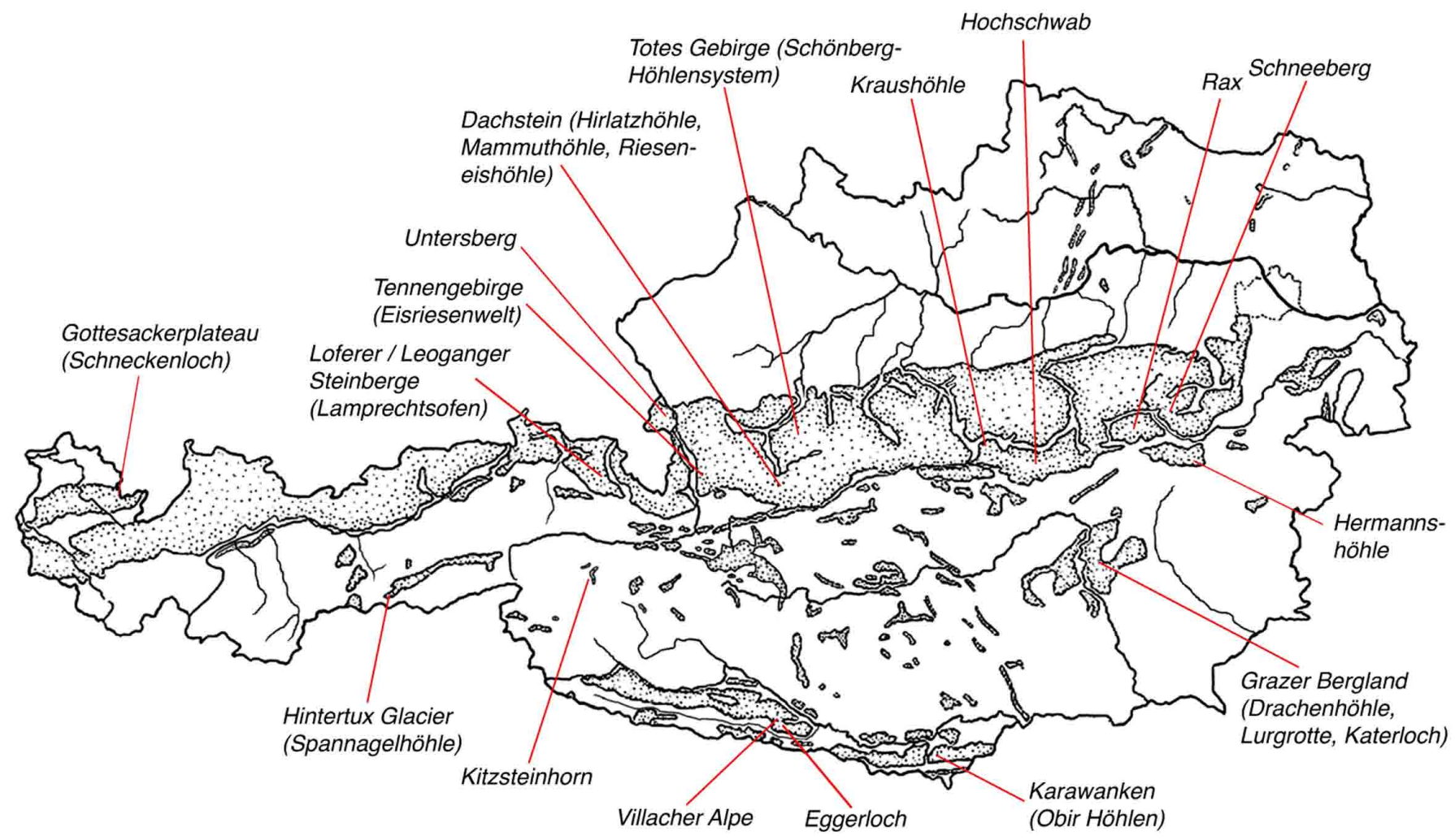

Fig. 1. Map of Austria showing the distribution of karstifiable rocks (limestone and dolomite). Arrows indicate selected karst regions and important caves mentioned in the text.

central and eastern segments of the NCA formed a low-lying, subsiding area during the Oligocene and earliest Miocene with deposition of fluvial gravels (Augenstein Formation). Extensive karst aquifers developed in the thick, commonly flat lying Triassic platform carbonates beneath (Denneborg, 2001). Uplift commenced in this part of the Eastern Alps only about 10 million years ago (Upper Miocene - Frisch et al., 2000) as a result of orogen-wide extensional stress and gave rise to distinct levels of karst aquifers, today's cave systems (Fischer, 1990, Audra et al., 2002, 2007, Frisch et al. 2008). These include the oldest and highest cave level at approximately $2100 \mathrm{~m}$ (Ruinenhöhlen-Niveau, ruin cave level), currently being destroyed by surface erosion, the cave labyrinths at 1500-1700 m (RiesenhöhlenNiveau, giant cave level; Fig. 3), which encompass most of Austria's largest and well-known caves, and the deepest horizon (Quellhöhlen-Niveau, spring cave level), today's hydrologically active (i.e. phreatic) cave level. In essence, most of the large, near-horizontal cave systems in the NCA above approximately 1500 $\mathrm{m}$ altitude are relics of extensive Tertiary aquifers that drained waters from the Central Alps toward the northern foreland. These phreatic conduits were later modified by vadose processes. A similar evolution took place in the Grazer Bergland. There, large conduits developed progressively at different levels during the Tertiary, related to terraces of the Styrian Basin in the south (Bauer \& Zötl, 1972). Although some of the structurally deeper systems harbor perennial vadose streams today - the Lurgrotte between Semriach and
Peggau being an example (Behrens et al., 1992) - most passages are fossil, including the huge tunnel of the Drachenhöhle near Mixnitz.

\section{Palaeoclimatic control on karst}

Palaeogeographic reconstructions show that the area of the Austrian Alps was surrounded by shallow epicontinental seas of the Neotethys during Oligocene and Miocene times (Steininger \& Wessely, 2000). Caves in the Grazer Bergland, including Lurgrotte and Katerloch, lay within $15 \mathrm{~km}$ of the coastline during times of sea-level highstands (Middle Miocene, 17-12 million years ago). Palaeobotanic evidence suggests a subtropical climate during this time, giving rise to wide-spread peat deposition in near-coastal swamps. The central and eastern NCA were probably densely forested lowlands, and well-developed soils in conjunction with high rainfall and warm average temperatures resulted in high rates of karstification. A conspicuous sedimentological feature attributable to this early phase of subtropical cave development is a red, sticky loam found in many cave systems as well as in relics on the surface (Kuhlemann et al., 2008). These sediments, locally intermixed with Fe-oxide pisolites (Seemann, 1979; Clemens et al.,1995), do not form in today's temperate-humid to cold-humid climate and represent terra rossa-type palaeoweathering products. Another feature that may date back to the Tertiary origin of some of these karst systems are speleothems. Many caves are known to host large, fossil speleothems (stalagmites and flowstones). Their presence in caves at high altitude 


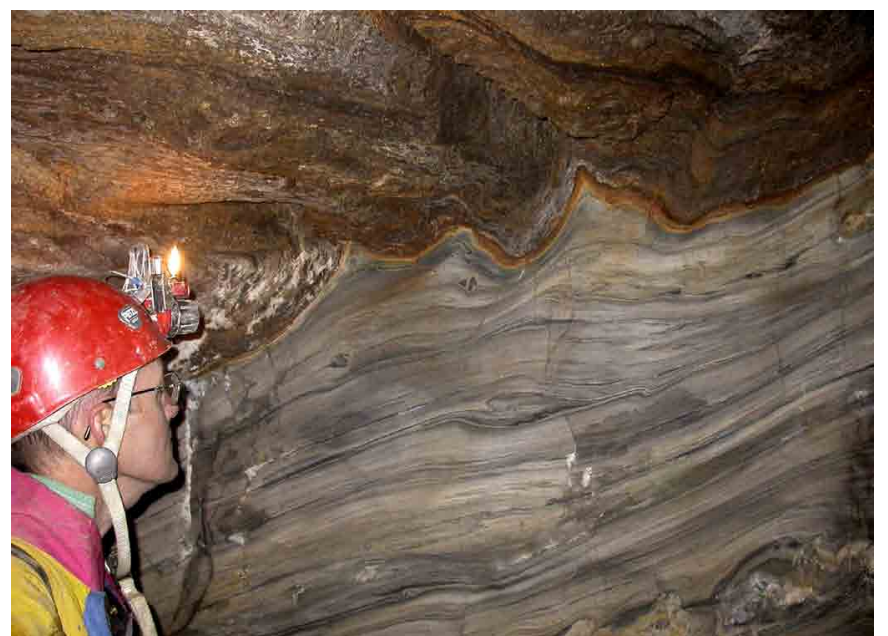

Fig. 2. Tectonic contact between gray, sheared calcite marble of Jurassic age and overlying, brown, altered gneiss schists of Permo-Carboniferous age in the Spannagelhöhle, Tyrol. This $10 \mathrm{~km}$-long high-elevation cave system developed within a 20 m-thick slab of marble bound by crystalline rocks.

and the common presence of neotectonic fractures dissecting these formations suggest an ancient origin. In addition, intensively weathered speleothem deposits at cave entrances demonstrate that significant time has elapsed since their formation. Several caves in the Central Styrian Karst, for instance, contain speleothem formations with large diameters which are reminiscent of speleothems in caves of the Mediterranean region. The entrance part of Katerloch, one of Austria's most abundantly decorated dripstone caves, hosts a complex stalagmite column about $15 \mathrm{~m}$ in diameter. It is tempting to interpret these large formations, which are clearly inactive today, as relics of a subtropical Tertiary climate. The only attempt to radiometrically date large, fossil stalagmites from Austrian caves was largely unsuccessful (using the $\mathrm{U} / \mathrm{Pb}$ method; Frisch et al., 2001). The U content of two large stalagmites from the Dachstein-Mammuthöhle and from the Eisriesenwelt, both belonging to the giant cave level, was too low, but the $\mathrm{U}$ and Th isotope data indicated an age in excess of 0.5 million years and probably but less certain - older than 1.5 million years (Frisch et al., 2001). A regional U/Th study of several caves in Austria confirms the common presence of speleothem deposits older than ca 0.4-0.5 million years, attesting to the high age of these caves (Spötl et al., 2007; Boch et al., 2006, and unpublished results). Recently, high $\mathrm{U}$ contents permitted to date flowstones in two highalpine caves from the Allgäu Alps precisely to 1.7 and 2.0 million years, respectively (Meyer et al., 2009).

Climate changed profoundly from Miocene to modern times. The Neotethys sea retreated, perialpine foreland basins were filled by erosion products from the rising alpine mountain arch, and the waxing and waning of mountain glaciers resulted in the well-known alpine topography with U-shaped and overdeepened valleys filled by thick, glacially-derived sediments. Although the role of Pleistocene glaciations on karst development in the Eastern Alps is still a matter of debate, it is generally assumed that glacial melt waters utilised and modified pre-existing underground drainage pathways (the Tertiary palaeoconduits) and gave rise

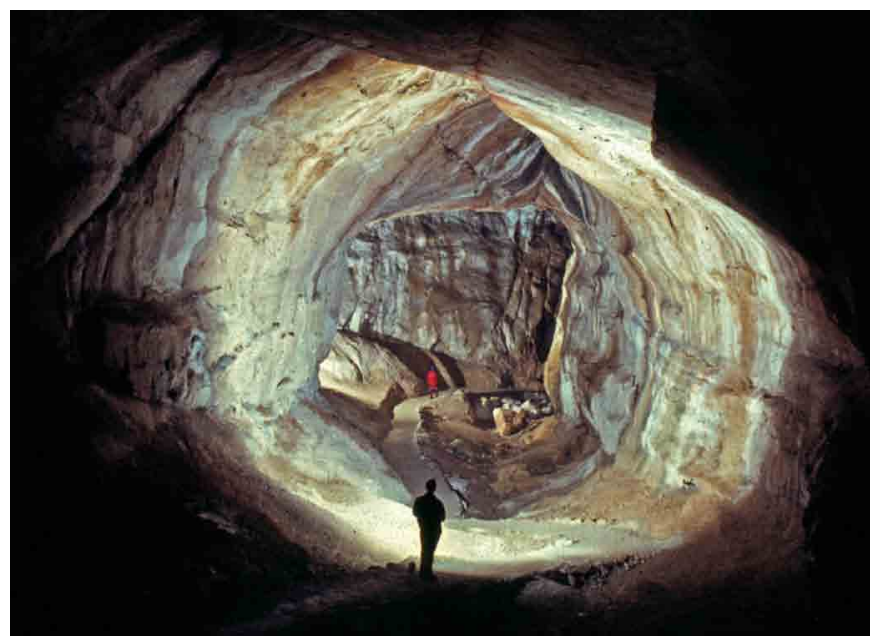

Fig. 3. Fossil phreatic tunnel, the so-called Paläotraun, in the Dachstein-Mammuthöhle (Obertraun, Upper Austria). Photo courtesy W. Hartmann.

to the development of vadose shafts which extend from the karst plateaus down to these palaeoconduits (and locally deeper). It is rather unlikely, however, that entirely new cave systems formed during glacials (e.g., Audra, 2004, 2007). Except for perched aquifers, the present-day karst water table typically corresponds to the altitude of the valley floors. This results in a commonly very thick unsaturated zone, as shown by a number of vadose shafts approaching and exceeding $1 \mathrm{~km}$ in depth (e.g., Bauer, 1969; Plan et al., 2009). Present-day karst development is widespread in Austria, although at a significantly smaller scale than during the warm and humid Tertiary climate. Modern karst is the result of dissolution by meteoric water charged with carbon dioxide on its way through the soil horizon. This classical karst process is bound to low to mid altitudes where vegetation cover is dense and soils are well developed. Carbon dioxide production and its partial pressure in the soil decrease with increasing altitude, resulting in low dissolution capacities above about 1600-1800 m (transition from green karst, covered by forests, to alpine meadows and finally bare rock (naked karst)). This coincides largely with the altitudinal range of the timberline in the Eastern Alps (Veit, 2002). Caves located above the timberline are either (tectonically uplifted) relics of Tertiary karst and/or hydrologically related to glaciated areas. Although uniformly retreating since the 1980 s, glaciers are widespread in the Central Alps of Austria, where the equilibrium line altitude is presently between 2600 and $2900 \mathrm{~m}$ (Veit, 2002). Caves located near glaciers partially owe their existence to melt waters, which are typically undersaturated with respect to carbonate minerals and are consequently capable of dissolving soluble rocks where initial (fracture) porosity permeability is present. Moreover, these glacier-derived waters show very high seasonal discharge which, in conjunction with abundant silt and sand size particles (rock flour), mechanically abrade the subsurface. This effect is particularly significant in regions where both carbonate and crystalline (quartz-bearing) lithologies 
are present and the debris from the latter abrades the softer carbonate rocks.

\section{Modern cave environments}

Given the large altitudinal range, caves in Austria show a wide spectrum of cave climate conditions. Interior cave air temperatures, known to mimic the mean annual air temperature outside (cf. Wigley \& Brown, 1976), range from ca. $+10^{\circ} \mathrm{C}$ down to a few degrees below the freezing point. Relative humidity values typically remain near condensation, except for near-entrance regions and passages with a strong draught. The partial pressure of $\mathrm{CO}_{2}$ varies inversely as a function of the cave's altitude (as well as the intensity of cave ventilation), reflecting the proximity to and the bioproductivity of the soil horizon. Most large Austrian caves show $\mathrm{pCO}_{2}$ values ranging from slightly above the atmospheric value (2009: $387 \mathrm{ppmv}$ ) to a few thousand ppmv. Concentrations of the radioactive noble gas $\mathrm{Rn}$ commonly (but not strictly) vary sympathetically with $\mathrm{pCO}_{2}$ values, but are typically significantly more sensitive to small variations in air flow.

A special aspect of several caves in this country is the presence of thick accumulations of perennial ice (Fig. 4). These ice caves are considered to be the largest on this planet, including the Eisriesenwelt in Werfen and the Dachstein-Rieseneishöhle in Obertraun, both top tourist attractions. Although trapping of cold winter air is known to be the controlling factor of ice formation and preservation in small, sagtype caves, most of the large ice caves owe their ice deposits to cooling by unidirectional air flow. Ice caves of the "Dachstein Cave Park" (central NCA) are the most intensively studied sites; detailed accounts of ice thickness variations and air flow patterns are available (Saar, 1956; Pavuza \& Mais, 1999). Several ice caves, in particular those of the sag-type, show a decrease in ice thickness since several decades. Large, dynamically ventilated ice caves, however, do not follow this simple pattern and their mass balance is controlled by local factors (e.g., Wimmer, 2008). Radiocarbon dates of wood fragments embedded in ice suggest that, although some ice in alpine ice caves may be up to a few thousand years old, most appears to have formed during the so-called "Little Ice Age" (ca. 1250-1850). At that time, the climate in large parts of Europe was significantly colder and glaciers advanced considerably.

\section{Karst hydrogeology}

Although Austria has a large surplus of water because of the high mountains (Fig. 5), its water supply depends critically on karst ground water from large karst springs (Schubert, 2000). Half of the country's population utilises karst water. The cities of Graz, Salzburg, Villach, and Innsbruck are to a large extent supplied by drinking water from karst areas. The most outstanding example is the capital Vienna. Two water lines deliver high-quality water from remote karst regions of the NCA to Vienna: the First Vienna Water Line, operating since 1873, drains water from

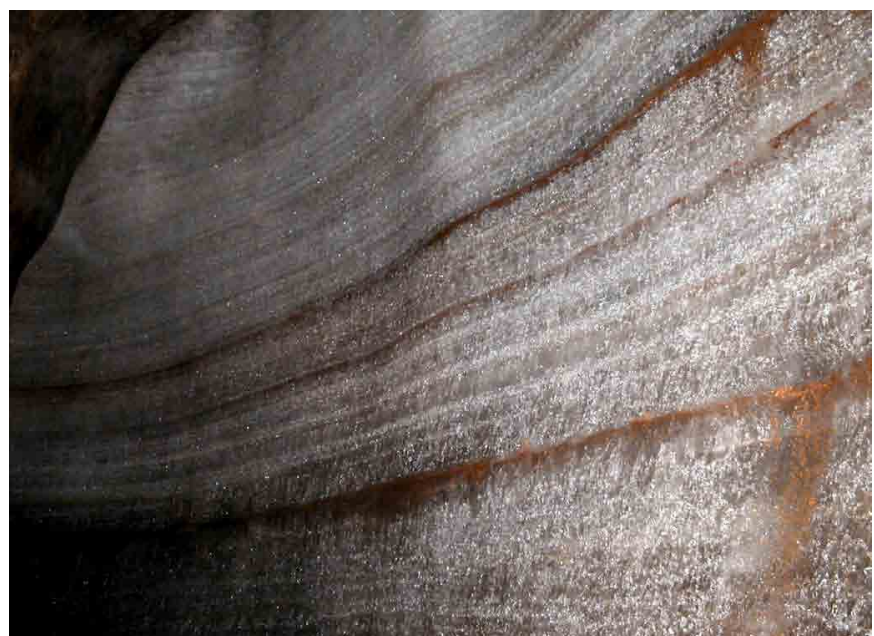

Fig. 4. Stratified perennial ice in the Kolowratshöhle, Untersberg, Salzburg, showing red loamy layers. Maximum thickness of ice in the left part of the picture reaches about $4 \mathrm{~m}$. This ice deposit has been steadily declining since systematic observations started in the second half of the $19^{\text {th }}$ century.

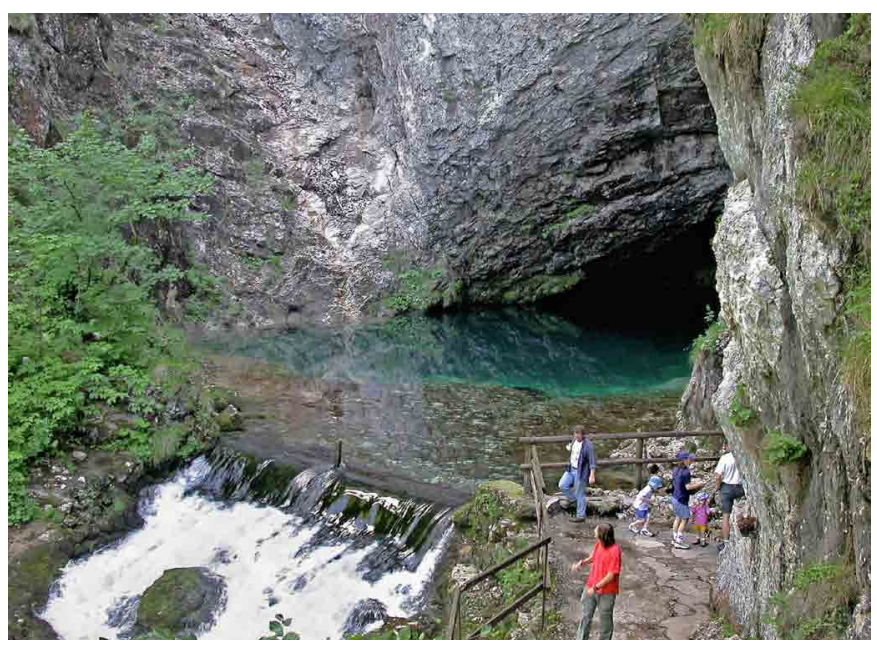

Fig. 5. Pießling Ursprung, a prominent karst spring near Windischgarsten in the province of Upper Austria. This picture was taken at low discharge during mid-summer; peak discharge can reach nearly $40 \mathrm{~m}^{3} / \mathrm{s}$.

the Rax and Schneeberg massifs. In 1910 the Second Vienna Water Line was opened and consists of a 220-km-long pipeline which transports (free flowing) water from the northern fringe of the Hochschwab Massif to the capital.

Karst spring water in the NCA has a low temperature $\left(5-8^{\circ} \mathrm{C}\right)$, is typically slightly alkaline $(\mathrm{pH}$ mostly $7.5-$ $8.0)$, shows low to intermediate carbonate alkalinity (6-18 German hardness) and is mostly of the Ca-Mg$\mathrm{HCO}_{3}$-type (e.g., Herlicska \& Lorbeer, 1994; Kralik et al., 2005). Hydrographs are characterised by a prominent discharge maximum during spring and early summer, reflecting snowmelt in the high-lying infiltration areas. Because of the well-developed karst network, travel time is typically on the order of a few days (Scheidleder et al., 2001). These karst aquifers are therefore highly vulnerable to contamination and require well-designed protection strategies, in particular in regions with intensive alpine land use (farming, tourism). 


\section{BIOSPELEOLOGY}

Austrian entomologists promoted the development of biospeleology during the second half of the $19^{\text {th }}$ century by describing cave arthropods from the the Classical Karst and the Kočevje district in the former Duchy of Carniola (Christian, 2003). In the larger part of present-day Austria, however, cave invertebrates have been ignored until the 1920s. The reason was the apparent lack of troglomorphic beetles in the NCA. Karl Holdhaus had explained the absence of blind soil beetles in the area north of the rivers Gail and Drau (Drava) with Pleistocene extinction (Holdhaus, 1906). Tacitly expanding this hypothesis, biospeleologists denied the existence of troglobiont animals in the NCA. The difference to the cave fauna of the Southern Calcareous Alps was striking because the narrow strip along the southern border of Austria had yielded a variety of troglobionts, including blind beetles.

It was a paradigm shift when Josef Meixner described the eyeless carabid Arctaphaenops angulipennis (Fig. 6) from a cave in the Dachstein (Meixner, 1925). The Holdhaus theory, though firm in its central thesis of Pleistocene species decline in soil and underground habitats of the Northern Alps, did not apply to single "lucky ice-age survivors"! Searching for troglobiont animals in formerly glaciated regions was no longer a forlorn attempt. Even some older material appeared in a new light, as shown by records of cave palpigrades (Fig. 7) released immediately after the Arctaphaenops publication (Wettstein-Westersheim, 1926; Wichmann, 1926; see Vornatscher, 1950).

At that time Hermann Spandl presented a monograph on the fauna of subterranean waters (Spandl, 1926) in the series Speläologische Monographien launched by Georg Kyrle, the only professor of speleology ever installed at an Austrian university. Groundwater zoologist Dan Danielopol refers to Spandl as the founder of modern groundwater ecology (Danielopol, 2001). This branch of subterranean biology has flourished in Austria since the late 1960s. Research has been focused on hyporheic habitats, on saturated porous aquifers and, to a lesser extent, on springs in karst and non-karst areas. The Danube alluvial aquifer in the Vienna Basin turned out to be a hotspot of subterranean biodiversity, with as many as 35 stygobiotic species (Danielopol et al., 2000; Danielopol \& Pospisil, 2001; Pospisil, 1994, 1999). Investigations during the last twenty years, principally by Martin Haase, uncovered a high species richness of hydrobiid snails in Austria (see Reischütz \& Reischütz, 2009). Cave water communities in the proper sense are poorly studied, with the exception of Lurgrotte north of Graz (Neuherz, 1974, and a current investigation by Fabio Stoch, Trieste; the terrestrial fauna of this cave was described by Neuherz, 1975). The epikarst habitat is still largely unexplored.

Josef Vornatscher, the dominant figure of Austrian biospeleology for half a century, started off around 1930. He was inspired by zoological investigations of Hans Strouhal in the caves near Villach in southern Carinthia (Strouhal, 1939, 1940). Vornatscher forwarded his material to leading taxonomists who

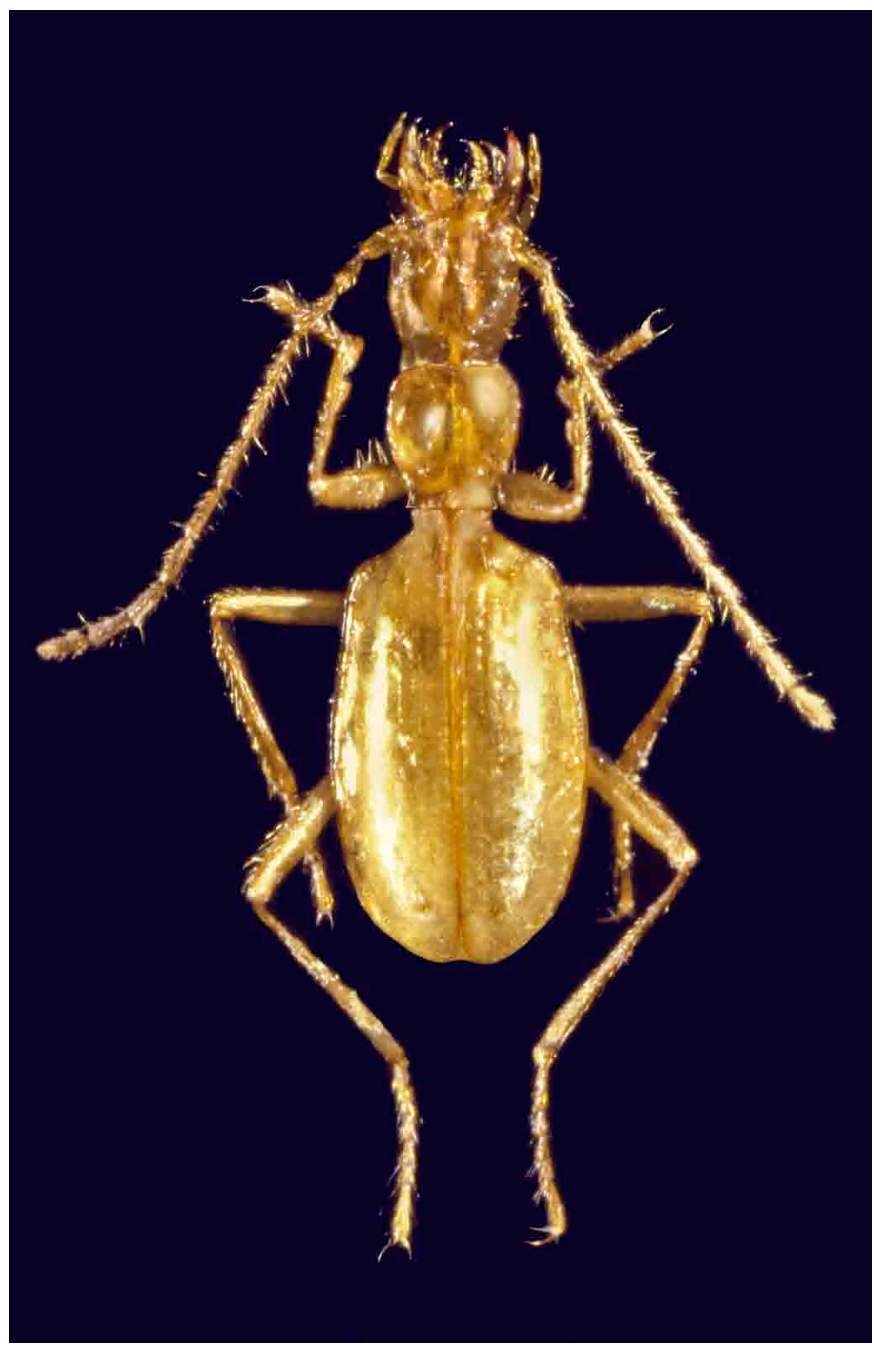

Fig. 6. Arctaphaenops angulipennis, type species of the single genus of blind ground beetles in the Northern Calcareous Alps. The endemic genus is distributed partly within the area of Pleistocene glaciation, partly in the periglacial zone (compare Fig. 8).

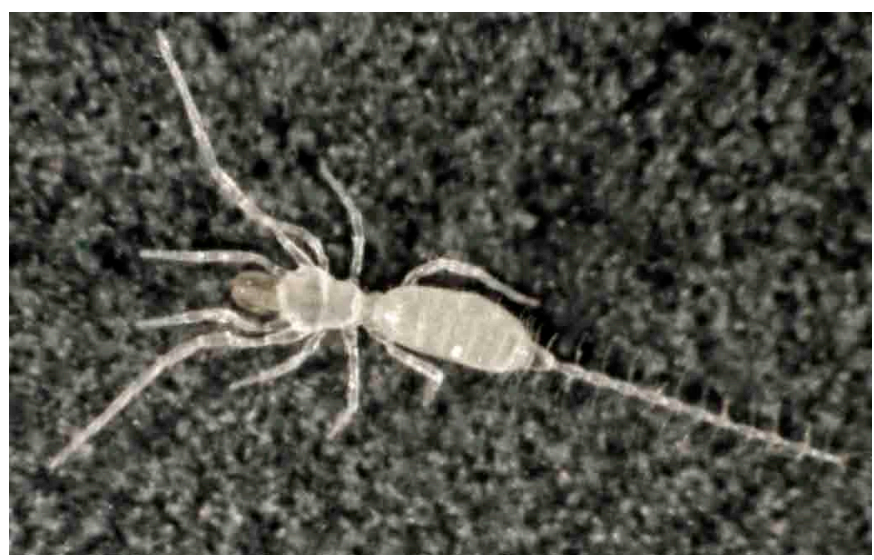

Fig. 7. In Austria, the palpigrade Eukoenenia spelaea has been recorded both in caves and in the milieu souterrain superficiel. Photo L. Kováč.

described several new arthropod species. For a catalogue of Austria's recent cave animals Vornatscher compiled own data, files of the late Hans Strouhal and all relevant literature (Strouhal \& Vornatscher, 1975).

Starting 1940, Karl Mandl published new taxa of bathysciine beetles from caves and mining galleries in the South Carinthian Karawanken Mountains. The range of the carabid genus Arctaphaenops, endemic to the eastern NCA (Fig. 8), took shape from the mid 


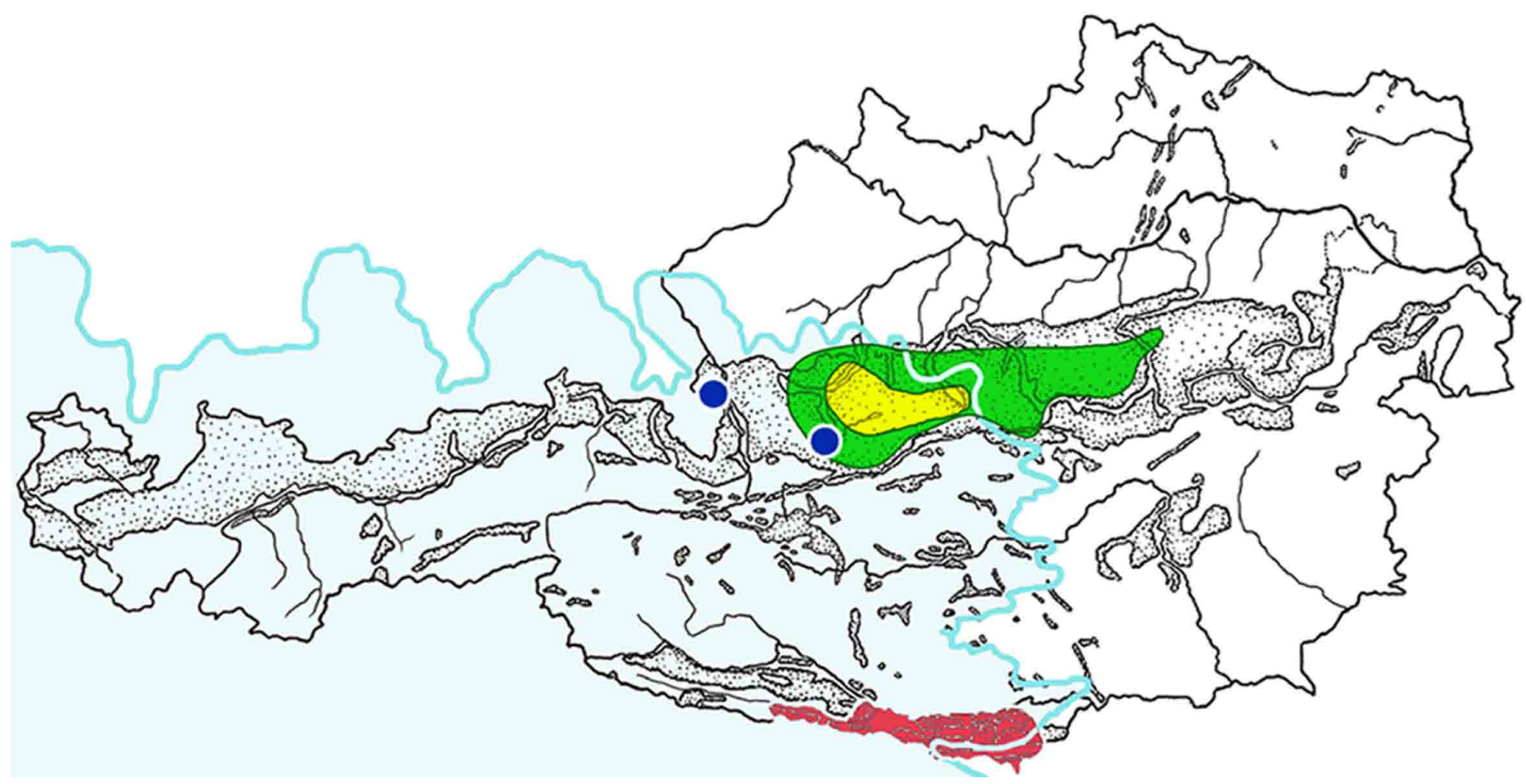

Fig. 8. Distribution of prominent cave-dwelling invertebrates in relation to the maximum extension of the Pleistocene glaciation in Austria (shaded blue; nunataks and small isolated glaciers in the perglacial area not plotted). The range of Anophthalmus beetles (red) covers most of Austria's Southern Calcareous Alps which house, compared to the rest of the country, a higher biodiversity of true cave dwellers. Troglobiont taxa endemic to the Northern Calcareous Alps are the ground beetle genus Arctaphaenops (green), the pseudoscorpion Neobisium aueri (yellow) and the millipede Typhloiulus seewaldi (blue).

1960s on, when Manfred Schmid described most of the nominal species (Christian, 2004 a). In 1962, Max Beier presented another show-piece of the NCA cave fauna, the troglomorphic pseudoscorpion Neobisium aueri (Fig. 9).

Taxonomy and biogeography are central, but not the sole fields of biospeleology in Austria. Karl Mais published an eco-physiological study of two cavedwelling springtail species (Mais, 1969). Gerald Kastberger uncovered ethological traits of the cave cricket Troglophilus cavicola (see Ensifera below). For her doctoral thesis at the University of Münster, Germany, Evelyn Rusdea conducted a series of outdoor and laboratory investigations into the life history and evolutionary biology of the ground beetle Laemostenus schreibersii (see Rusdea, 1998).

\section{Habitats of subterranean land fauna}

Caves have been inspected for underground biota for more than one and a half centuries. But while even early groundwater zoologists considered aquifers of all dimensions, students of land-living subterranean fauna confined their research to chambers and passages accessible to humans for a long time. It was chiefly the realisation of a milieu souterrain superficiel (MSS) in the 1980s (Juberthie et al., 1980) that broadened classical biospeleology towards a general subterranean biology.

Thereupon the investigation of smaller spaced cavities, in solid rock as well as in unconsolidated sediments, started also in Austria. Several papers deal with the interstitial collembolan biodiversity in littoral and inland sands (e.g., Thibaud \& Christian, 1997). Faunas of MSS-type habitats were repeatedly sampled. Christian $(1985,1987,1993)$ studied an ice-bearing talus slope in southern Carinthia and a similar extrazonal permafrost soil in Lower Austria. Spider records from Tyrolean MSS habitats in the NCA and the Central Alps were published by Ruzicka \& Thaler (2002). Zacharda (2000 a, b, c, d, 2001) investigated rhagidiid mites in talus deposits of the Ötztal Alps, Tyrol, and found a number of new species.

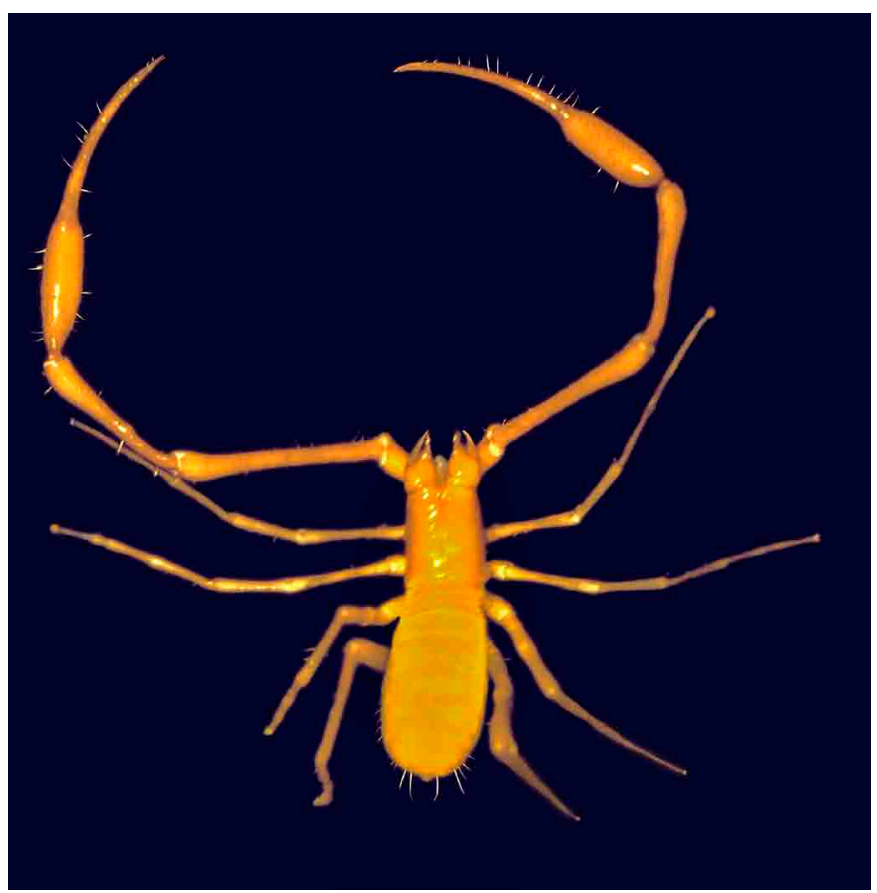

Fig. 9. Neobisium aueri. The range of this troglomorphic pseudoscorpion is confined to the Totes Gebirge and the adjacent Warscheneck Mountains just within the area of Pleistocene glaciation (compare Fig. 8). 
A peculiar habitat was explored by Christian (1998 a, b, c) in the Pleistocene gravel floor of the catacombs of St. Stephen's Cathedral in the heart of Vienna. Significant results of this study were first Austrian records of subterranean springtails, the discovery of a new springtail species, and the record of the palpigrade Eukoenenia austriaca which previously had been known only from caves.

\section{Faunal survey}

The following compilation of multicellular invertebrates from Austrian caves is far from exhaustive. This is partly caused by the different views of what we call a cave animal. If information on life cycle, specific ecological demands and distribution are available, a species from the air-filled cave environment can be readily classified, for instance in terms of the trogloxene/troglobiont spectrum. Nevertheless, the colloquial expression "cave animal" remains ambiguous. It may be limited to obligatory dwellers of proper caves or extended to animals with any specified relationship to any cave-like habitat. Here we register the troglobiont and many of the eutroglophilic and subtroglophilic terrestrial fauna of Austria. Intricate is the distinction between cave water and ground water dwellers, again mainly for terminological reasons. But even a more appropriate differentiation into the animal assemblages of porous, fissure, and karst waters carries some ambiguity. Hence we include a selection of aquatic species which have been recorded chiefly from subterranean habitats in Austria, whether or not they were sampled in caves.

The nomenclature was implicitly adapted to current usage where necessary. References to (sub)species names are given without comma between author and year, yet fully referenced in cases they provide information on the Austrian fauna.

\section{Turbellaria}

Flatworms of Austrian caves are poorly studied. Old records (e.g., in Strouhal \& Vornatscher, 1975) should be re-examined. Neuherz (1974) found in the Styrian Lurgrotte 11 species, three of which he regarded as stygobiont: Phagocata paravitta (Reisinger 1923), $P$. racovitzai (de Beauchamp 1932), and Dendrocoelum nausicaae Schmidt 1861. The groundwater planarians Dendrocoelum maculatum candidum Kenk 1978 and $P$. paravitta are known exclusively from Austria, but Kenk (1974) suspects the latter to be a synonym of the South European P. olivacea (Schmidt 1861).

\section{Nematoda}

Eder (1979) published one of the very few contributions to the nematode fauna of Austrian caves and reported, among others, the possibly eutroglophilic species Cephalobus troglophilus Andrássy 1967 from Hermannshöhle. Theristus franzbergeri Schiemer 1984, a groundwater nematode of marine origin, is an endangered species endemic to the Vienna region.

\section{Gastropoda}

Two taxa of underground Carychiidae, Zospeum isselianum Pollonera 1887 and Zospeum alpestre kupitzense Stummer 1984, occur in the Southern Calcareous Alps, at the northern border of the range of the genus. They inhabit fissures rather than spatious caves (Maier \& Gressel, 1977). Hydrobiidae in subterranean waters and springs exhibit a high level of endemicity. Reischütz \& Reischütz (2009) list 31 extant species and one subspecies as endemic to Austria (of about 40 hydrobiid species group taxa altogether: Fischer, 2007), belonging to the genera Alzoniella, Belgrandiella, Bythinella, Bythiospeum, Graziana, Hauffenia, and Iglica (Reischütz, 1988, 1997; Haase, 1992, 1993 a, 1993 b, 1994, 1995, 1996; Fischer \& Reischütz, 1995; Haase \& Mildner, 1996; Haase et al., 2000). Half the endemic (sub) species were described during the past 20 years. Internal anatomy has been considered in many of the more recent descriptions and revisions (e.g., Haase, 1995).

\section{Annelida}

The stygobiont polychaete worm Troglochaetus beranecki Delachaux 1921 is widespread in Austrian ground waters, but seldom captured. Tilzer (1973) studied the dispersal ability of $T$. beranecki in an interstitial habitat. Cave records are missing in Austria. Neuherz (1974) ranks Aeolosoma hemprichi Ehrenberg 1831 among the stygophilic biota of Lurgrotte.

\section{Araneae}

Trogloneta granulum Simon 1922 and Porrhomma myops Simon 1884 were reported from MSS habitats in rock stream and talus deposits (Breuss, 2001; Ruzicka \& Thaler, 2002; Thaler, 1975). Due to their preference for rock fissures and mammal burrows, species of the linyphiid genus Troglohyphantes appear predisposed to underground life. T. novicordis Thaler 1978, described from a cave in Central Styria, is obviously a high-grade eutroglophile. T. typhlonetiformis Absolon \& Kratochvil 1932 had been known only from Slovenian caves before Thaler (1999) recorded this single troglobiont spider species of Austria in the Lobnikschacht near Eisenkappel, southern Carinthia. The frequency of occurrence and the obvious cocoons make Meta menardi (Latreille 1804) one of the best-known cave animals (Fig. 10).

\section{Palpigradi}

Five closely related taxa, currently attributed to two species, occur in Austrian caves and MSS habitats (Christian, 2008 a): Eukoenenia spelaea spelaea (Peyerimhoff 1902), E. spelaea vagvoelgyii (Szalay 1956), E. spelaea strouhali Condé 1972, E. austriaca stinyi (Strouhal 1936), and E. austriaca styriaca Condé \& Neuherz 1977. The Austrian range of $E$. spelaea (Fig. 7) covers nearly the entire range of the NCA, the Central Styrian Karst, and the Saualpe in Carinthia, whereas E. austriaca has been recorded from the Villacher Alpe (Carinthia) and the Central Styrian Karst northward to the center of Vienna (Christian, 1998 b, 2004 b). 


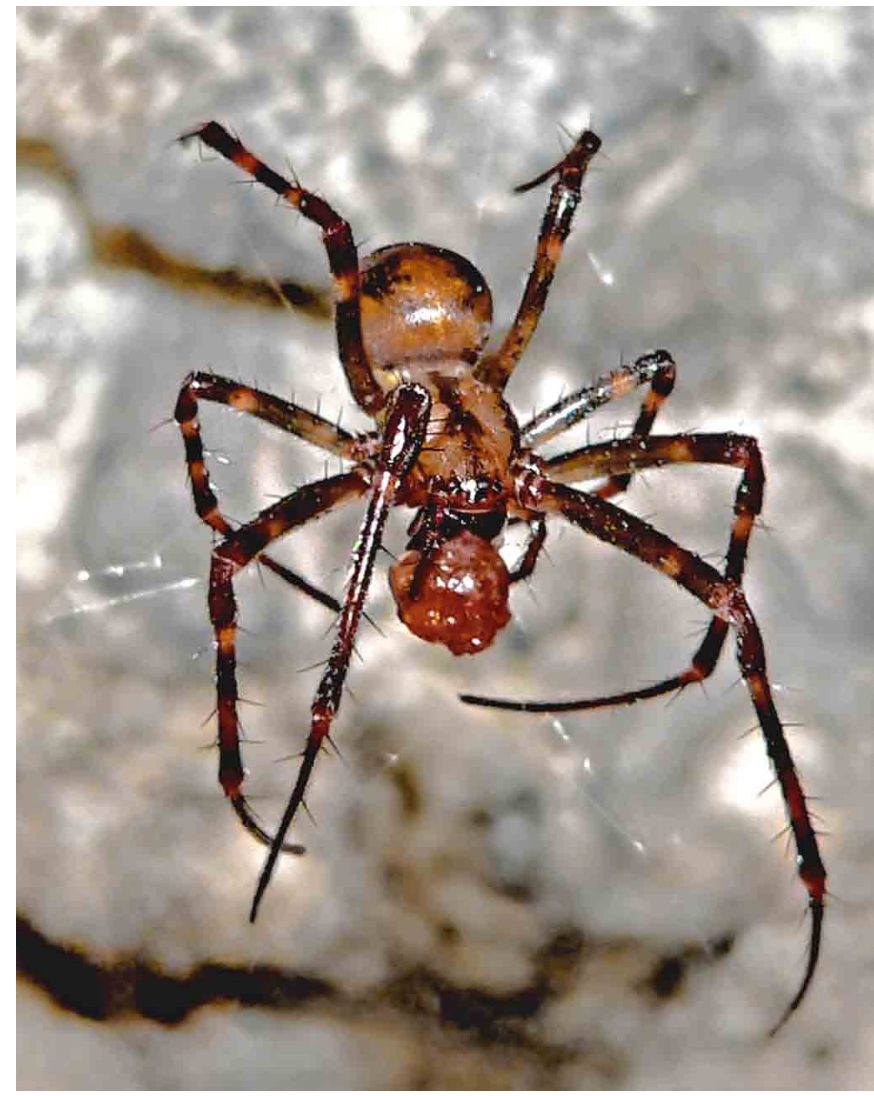

Fig. 10. The impressive spider Meta menardi is virtually omnipresent in the entrance regions of caves.

\section{Pseudoscorpiones}

Eutroglophilic species are Chthonius ellingseni Beier 1939 in Carinthia and Neobisium hermanni Beier 1938, originally described from Hermannshöhle in Lower Austria. Roncus carinthiacus Beier 1934, a troglobiont neobisiid of southern Carinthia, is blind but otherwise little troglomorphic. Fig. 8 shows the distribution area of the single troglobiont pseudoscorpion of the NCA, the conspicuously troglomorphic Neobisium aueri Beier 1962 (Fig. 9). The species is endemic to the Totes Gebirge and Warscheneck Mountains (for records see Gaisberger, 1984).

\section{Opiliones}

Among the subtroglophilic harvestmen, Amilenus aurantiacus (Simon 1881) is most frequently observed in caves, sometimes in hibernating colonies of thousands of individuals. Ischyropsalis carli Lessert 1905 and I. helvetica Roewer1906 extend from Switzerland over the western provinces Tyrol and Vorarlberg (Breuss, 2004), whereas the likewise eutroglophilic I. kollari C.L. Koch 1839 inhabits a larger area from Tyrol eastward. I. hadzii Roewer 1950, the only troglobiont harvestman of Austria, is an endemic species of the Karawanken and the Steiner Alps in Carinthia and Slovenia (Komposch \& Gruber, 2004).

\section{Acari}

Parasitus loricatus (Wankel 1861) is a frequently reported eutroglophilic mite. Another representative of the Mesostigmata, Amblyseius caviphilus Karg 1986, was described based on females that inhabited abandoned cocoons of Meta menardi in two Lower Austrian caves. A study of the oribatid fauna of Hermannshöhle (Bruckner, 1997) yielded ten species, including Pantelozetes cavatica (Kunst 1962) and Oppiella keilbachi (Moritz 1969). Rhagidiid mites occur in caves as well as in MSS habitats. The most prominent cavernicolous members of this family belong to the troglomorphic genus Troglocheles. T. archetypica Zacharda 2000 and T. aggerata Zacharda 2000 inhabit talus interstices in North Tyrol. T. strasseri (Willmann 1932), T. vornatscheri (Willmann 1953) and a lately detected new species from the Türkenloch, a cave near Kleinzell, Lower Austria, are problably troglobionts. Water mites of karst aquifers have been treated, inter alia, in a current research project on the fauna of springs in the Gesäuse National Park, Styria, which yielded first Austrian records of the arrenuroid Chelomideopsis annemiae Romijn 1920 and the hydryphantid Tartarothyas romanica Husiatinschi 1937 (Gerecke, 2009). Cave records of water mites are scarce. The widespread limnohalacarid Soldanellonyx chappuisi Walter 1917, reported from Hermannshöhle by Christian (1997), was occasionally also found in ground water, in springs and in the benthos of deep lakes.

\section{Copepoda}

A number of stygobiont Cyclopidae are known exclusively from Austria: Acanthocyclops gmeineri Pospisil 1989, Austriocyclops vindobonae Kiefer 1964, Diacyclops danielopoli Pospisil \& Stoch 1999, and D. felix Pospisil \& Stoch 1999, all of them collected in alluvial sediments of the Danube plain (Pospisil, 1989; Pospisil \& Stoch, 1999). The stygobiont Diacyclops cohabitatus Monchenko 1980, redescribed from the same area (Stoch \& Pospisil, 2000 a), occurs also in Mausrodlhöhle near Lunz am See (Stoch \& Pospisil, 2000 a). Diacyclops clandestinus (Kiefer 1926), another specialised stygobiont, was reported from Lurgrotte by Plesa \& Buzilă (1998). Diacyclops languidoides goticus (Kiefer 1931), a stygobiont subspecies described from the Postojna-Planina cave system in Slovenia (probably a valid species: Stoch \& Pospisil, 2000 a), was reported from a well in Bad Vöslau south of Vienna. The closely related Diacyclops languidusgroup is represented in Austria by the stygophilic Diacyclops disjunctus (Thallwitz 1927), redescribed from alluvial ground waters of the Lobau area (Stoch \& Pospisil, 2000 b), and Diacyclops languidus maisi (Plesa \& Buzilă 1998), exclusively known from the Central Styrian Lurgrotte (but probably a synonym of a more widely distributed groundwater species: F. Stoch, in litt.). Speocyclops cerberus (Chappuis 1934) from Kraushöhle in Styria had been considered endemic until F. Stoch (in litt.) identified this species from a karst spring in Trentino, Northern Italy. Several cyclopoid species reported from porous aquifers in Austria (see Pospisil, 1994; Gaviria, 1998), particularly Eucyclops graeteri (Chappuis 1927), Acanthocyclops rhenanus Kiefer 1936, A. sensitivus (Graeter \& Chappuis 1914), A. kieferi (Chappuis 1925), Graeteriella unisetigera (Graeter 1908), and G. laisi (Kiefer 1936), could likewise occur in cave 
environments, as indicated by their presence in cave waters of neighbouring countries.

Among stygobiont Harpacticoida, Nitocrella hofmilleri Brehm 1953 (in a well near Salzburg), Elaphoidella plesai Pesce \& Galassi 1994 (Lurgrotte, Styria) and E. proserpina Chappuis 1934 (Wilhelminenhöhle, Lower Austria; also present in the nearby Mausrodlhöhle: F. Stoch, in litt.) are endemic species (Gaviria \& Pospisil, 2009). The more widespread Elaphoidella elaphoides (Chappuis 1924) is present in porous ground waters, but has not been collected in Austrian caves as yet. Six Parastenocaris species have been recorded in porous ground water or hyporheic habitats: $P$. austriaca Kiefer 1976, P. brevipes Kessler 1913, P. fontinalis Schnitter \& Chappuis 1915, P. germanica Kiefer 1936, P. nolli Kiefer 1938, and P. phyllura Kiefer 1938 (the latter four occur syntopically in the Lobau wetland, Vienna: Danielopol \& Pospisil, 2001). The first sample of cavedwelling Parastenocaris, however, is currently under investigation (Lurgrotte; F. Stoch, in litt.).

\section{Ostracoda}

Five ostracod taxa are exclusively known from Austrian groundwater habitats (Gaviria \& Pospisil, 2009): the interstitial species Fabaeformiscandona tyrolensis (Löffler 1963) and the dwellers of porous ground water Mixtacandona laisi vindobonensis (Löffler 1963), M. spandli Rogulj \& Danielopol 1993, M. transleithanica (Löffler 1960), and Cryptocandona kieferidanubialis Namiotko et al. 2005. An undescribed Kovalevskiella species occurs in the Vienna Basin. The ostracod fauna of cave waters is poorly studied. Neuherz (1974) reported the palaearctic, stygophilic species Cavernocypris subterranea (Wolf 1920) from Lurgrotte.

\section{Syncarida}

Since the 1940s, when the first Bathynellacea were recorded in Austria, cave specimens (Fig. 11) have mostly been attributed to Bathynella natans Vejdovsky 1882 or Bathynella chappuisi Delachaux 1920. The determinations are doubtful, however. Antrobathynella stammeri (Jakobi 1954) and Bathynella vindobonensis Serban 1989 were extracted from groundwater samples.

\section{Amphipoda}

Older compilations of Austrian Niphargus records (e.g., Vornatscher, 1965; Straskraba, 1972) are largely obsolete. They listed up to twelve species, whereas Karaman (1992) reported only five, mainly from alluvial ground waters. The taxonomy of Niphargidae is still far from settled. On the basis of fresh material, F. Stoch (in litt.) identified the Lurgrotte population as Niphargus aggtelekiensis Dudich 1932 (contra $N$. tatrensis lurensis Schellenberg 1936, reported as $N$. tatrensis Wrzesniowsky 1888 by Neuherz, 1984). According to a current study (Fišer et al., in press), Austrian records of " $N$. tatrensis" (including Schellenberg's subspecies salzburgensis) or " $N$. $s p$. gr. tatrensis" pertain to N. aggtelekiensis throughout. As generally with Niphargus, however, molecular data

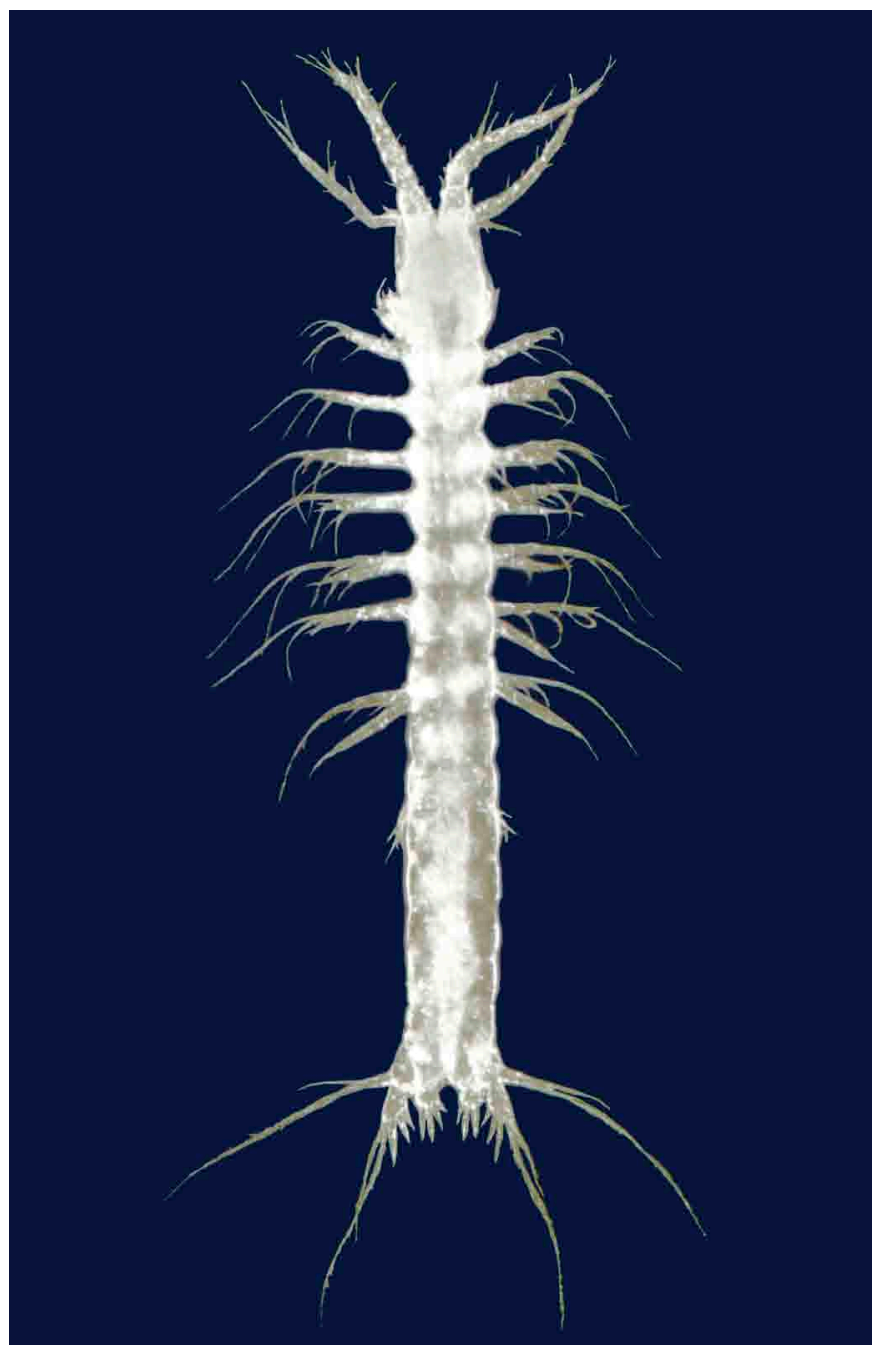

Fig. 11. Bathynella sp. netted in the "Pond" of Hermannshöhle, Austria's classical habitat of these syncarid crustaceans.

are required to evaluate this hypothesis. N. strouhali Schellenberg 1933, formerly considered as endemic to southern Carinthia (Eggerloch, Villach), and $N$. danielopoli Karaman 1994, described from Styria, were lately recorded in the Carnic Alps and other sites in Northern Italy (Karaman, 1994; Stoch, 2004). N. inopinatus Schellenberg 1932, redescribed by Karaman (1992), is distributed over Central Europe. Published Austrian records are from alluvial sediments between the Vienna and Salzburg regions and F. Stoch (in litt.) collected the species in the Mausrodlhöhle near Lunz am See. The type locality of $N$. schusteri Karaman 1991 is a well near Wildon, Styria, the single known locality of $N$. vornatscheri Schellenberg 1934 a well in the Prater floodplain, Vienna. High species density is occasionally found in porous ground waters. As many as six Niphargus species co-occur at a $0.8 \mathrm{~km}^{2}$ small sampling area in the Lobau floodplain of the River Danube, Vienna (N. bajuvaricus Schellenberg 1932, $N$. inopinatus Schellenberg 1932 and four species determined to group level), along with Niphargopsis casparyi (Pratz 1866) and Crangonyx subterraneus Bate 1859 (Danielopol \& Pospisil, 2001).

\section{Isopoda}

The only known troglobiont woodlouse of Austria, Trichoniscus styricus Strouhal 1958, was described 
from the Grasslhöhle in the Central Styrian Karst (Strouhal, 1958 a). Androniscus stygius tschameri Strouhal 1935 occurs in the Eggerloch (Villach, Carinthia: type locality) and in Slovenian caves. Mesoniscus alpicola (Heller 1858) lives under stones at higher elevations but becomes increasingly troglophilic towards the lowland (Fig. 12). Two subspecies of the ground water dwelling Proasellus slavus have been described on the basis of Austrian type specimens: $P$. slavus vindobonensis (Karaman 1955) and P. slavus salisburgensis (Strouhal 1958), both collected in alluvial sediments. The former cooccurs with $P$. strouhali (Karaman 1955) in the Lobau sampling area, Vienna (Danielopol \& Pospisil, 2001). $P$. strouhali is the most common stygobiont isopod in Austria, recorded from alluvial sediments, springs in Flysh and conglomerates (Strouhal, 1958 b), and caves (Mausrodlhöhle near Lunz am See: Strouhal, 1958 b; F. Stoch, in litt.). A still unidentified subspecies of Proasellus cavaticus (Leydig 1871) was reported by Strouhal (1958 b) from the Schneckenloch (Bregenzer Wald, Vorarlberg).

\section{Diplopoda}

Trachysphaeridae have been reported from several East Austrian caves. Specimens from the Lurgrotte were determined as Trachysphaera fabbrii (Verhoeff 1929), a species that also lives under stones on Mt. Ötscher, Lower Austria (Sillaber, 1986). The widespread polydesmid species Brachydesmus subterraneus Heller 1858 occurs in caves of the Villach region. Polydesmus xanthokrepis Attems 1898, endemic to the NCA, was collected in several Salzkammergut caves. Attemsiidae include a number of eutroglophilic species in Austria: Polyphematia moniliformis (Latzel 1884) in the NCA and at the eastern margin of the Alps (Thaler \& Neuherz, 1978); two members of the genus Syngonopodium, which is endemic to the NCA between the rivers Salzach and Enns (Gruber, 2009): S. aceris Verhoeff 1913 and S. cornutum Verhoeff 1929; Symphyosphys serkoi Strasser 1939 in the Griffner Tropfsteinhöhle (Carinthia); and the two species of the genus Tylogonium: T. nivifidele Strasser 1937 and T. hoelzeli Strasser 1959 in southern Carinthia. The eyeless julid Typhloiulus seewaldi (Strasser 1967) was originally described under the new genus name Alpityphlus from Hollerloch in the Untersberg south of Salzburg. As realized later, this cave was located a few hundred meters beyond the border to Bavaria, but eventually the single NCA species of the genus Typhloiulus has been recorded on Austrian territory in the Dachstein region (see Fritsch, 1998). $T$. seewaldi is the single troglobiont millipede of the country, known from the tunnel Warmwasserstollen a little above Lake Hallstättersee and the nearby cave Obere Brandgrabenhöhle in the northern part of the Dachstein Massif, Upper Austria (Fig. 8).

\section{Diplura}

The type localities of the troglobiont campodeids Plusiocampa strouhali Silvestri 1933 (Eggerloch) and Torocampa hoelzeli Neuherz 1984 (Hafnerhöhle,

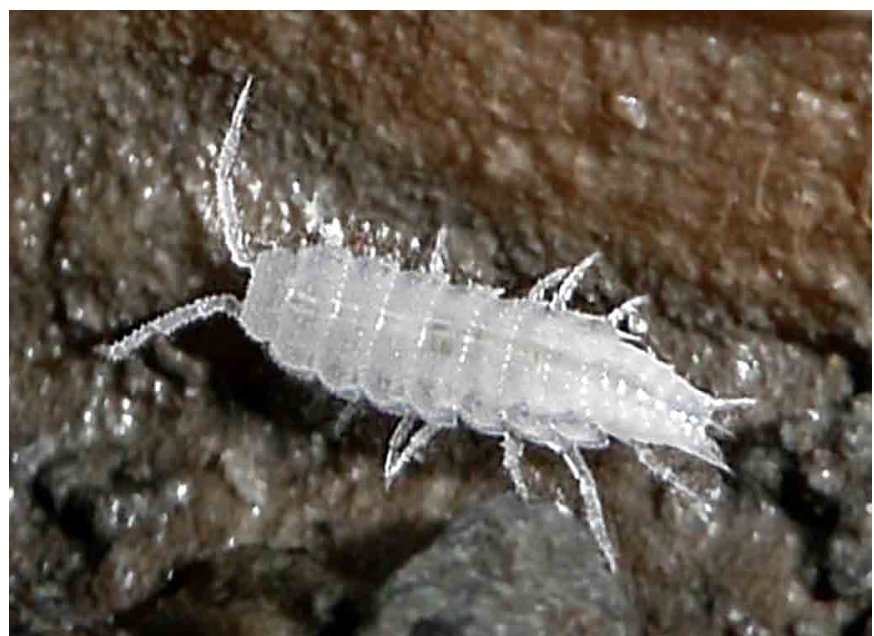

Fig. 12. The eyeless woodlouse Mesoniscus alpicola gets increasingly troglophilc with decreasing elevation.

Karawanken Mts.) are located in southern Carinthia. Records of Plusiocampa caprai Condé 1950 (Lombardy, Grisons, North Tyrol, Carinthian Central Alps) are mostly from caves, but also from alpine and dealpine surface habitats (Christian et al.,1996). The present author collected a specimen of the Plusiocampa spelaea group (det. H. Neuherz) in a Roman water conduit of ancient Carnuntum, eastern Lower Austria ( $P$. spelaea Stach 1929 was originally described from the Baradla Cave in northeastern Hungary). The intricate taxonomy of the troglobiont Plusiocampa populations occurring in the NCA is additionally nebulised by inconsistencies in nomenclature. Names such as P. cavicola Stach in litt. (nomen nudum) circulate in the literature. Records from caves in several provinces were assigned to $P$. strouhali cavicola Silvestri 1943 (in Vornatscher, 1943), a taxon that might contain a number of cryptic species. Rich Plusiocampa material from Austrian caves (leg. H. Neuherz) is held in the collection Bruno Condé, Nancy.

\section{Collembola}

Bonetogastrura cavicola (Börner 1901) (Fig. 13), Austria's most common hypogastrurid cave springtail, is distributed outside of the late Würmian ice shield. In terms of eye-reduction, the species displays increasing troglomorphy towards the interior of the Alps (Christian, 2002). Bonetogastrura spelicola (Gisin 1964) is endemic to the eastern part of the NCA. The single troglobiont neanurid species, Deutonura mirabilis Deharveng 1987, was described from a mining gallery in southern Carinthia. Onychiuridae account for the bulk of underground collembolan biodiversity. Cribrochiurus cribrosus (Gisin 1957) exhibits a scattered distribution within the area of Pleistocene glaciation in Switzerland and Austria (Fig. 14), whereas Micraphorura pseudoraxensis (Nosek \& Christian 1983), M. hackeri (Christian 1986) and $M$. melittae (Christian 1993) occupy the former periglacial part of the Alps. Deuteraphorura arminiaria (Gisin 1961), D. austriaria (Gisin 1962), D. trisilvaria (Gisin 162), D. quadrisilvaria (Gisin 1962), Onychiuroides cavernicolus (Stach 1934) and O. vornatscheri (Stach 1946) occur also mainly outside of the Würmian ice cover (Fig. 14; see Christian, 2002 for a discussion of 


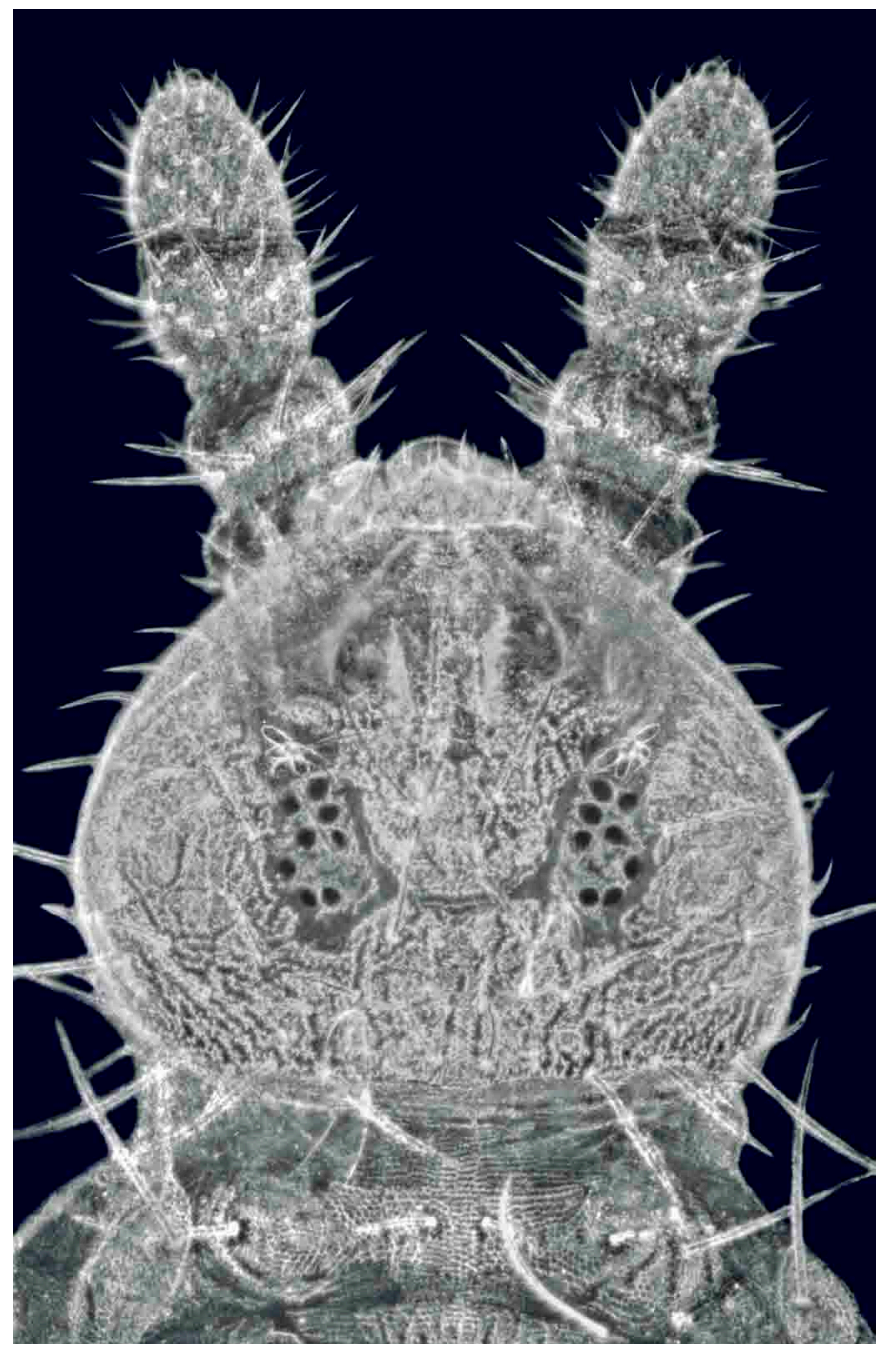

Fig. 13. Head of Bonetogastrura cavicola, a springtail species showing regionally varying eye-reduction. This specimen is from Dreidärrischenhöhle at the northeast margin of the Alps, where more than $90 \%$ of the individuals bear the complete set of $8+8$ eyes. distribution patterns). A Central Styrian cave species of unsettled generic affiliation (near Hymenaphorura) was described as Onychiurus reisingeri Neuherz 1979.

Gnathofolsomia palpata Deharveng \& Christian 1984, a possibly troglobiont species of a monotypic isotomid genus with modified, sweeping mouthparts, is endemic to the border triangle Salzburg - Upper Austria - Styria. Among Entomobryidae, Pseudosinella stands out for the variety of subterranean life-forms. Austrian species range from eye-bearing (e.g., $P$. duodecimpunctata Denis 1931 and P. seyleri Stomp \& Tommasi-Ursone 1989) over blind edaphomorphic (e.g., P. bidenticulata Barra 1967) to blind troglobiont forms with different degrees of troglomorphy. The latter are represented by the endemic species $P$. vornatscheri Gisin 1964, P. aueri Gisin 1964, $P$. salisburgiana Gisin \& Da Gama 1969 (Fig. 14), P. styriaca Neuherz \& Nosek 1975, P. christiani Stomp 1986 and P. passaueri Stomp, Tommasi-Ursone \& Christian 1991 (Stomp, 1986; Stomp \& TommasiUrsone, 1989).

Arrhopalites pygmaeus (Wankel 1860) is the most widespread subterranean springtail of the order Symphypleona. Another markedly eutroglophilic species, Disparrhopalites patrizii (Cassagnau \& Delamare Deboutteville 1953), was recorded in the catacombs of St. Stephen's Cathedral, Vienna, along with the neelid Megalothorax sanctistephani Christian 1998.

\section{Ensifera}

The ranges of the two subtroglophilic cave crickets (Rhaphidophoridae) of Austria were mapped by Moog (1982) and Christian (2008 b). Troglophilus cavicola (Kollar 1833) (Fig. 15) is distributed in the southern and eastern part of the country, whereas records of $T$.

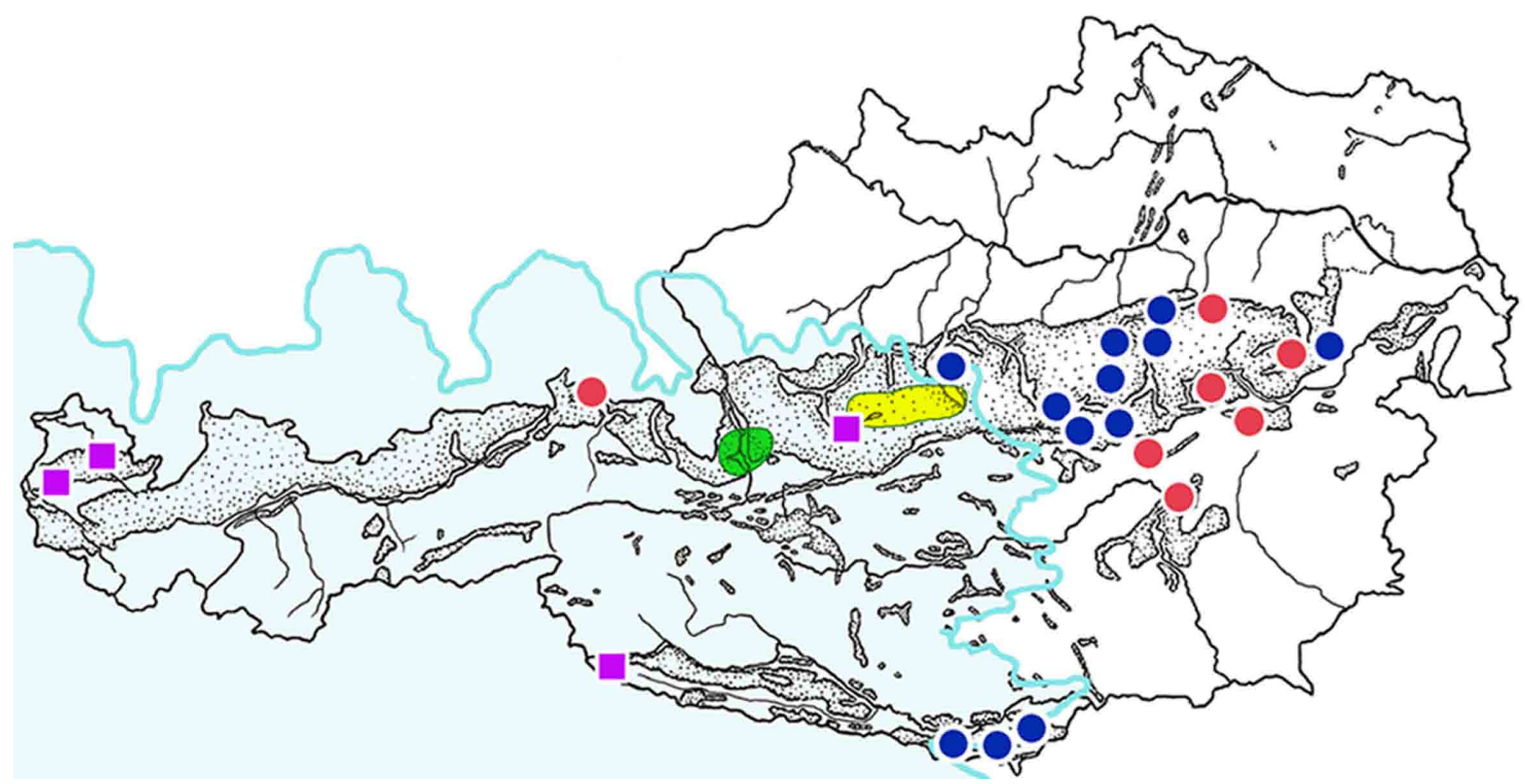

Fig. 14. Distribution patterns of cavernicolous springtails in relation to the maximum extension of continuous Pleistocene glaciations in Austria. Onychiuroides vornatscheri (blue), O. cavernicolus (red), Pseudosinella aueri (yellow), P. salisburgiana (green) and Cribrochiurus cribrosus (purple squares). 


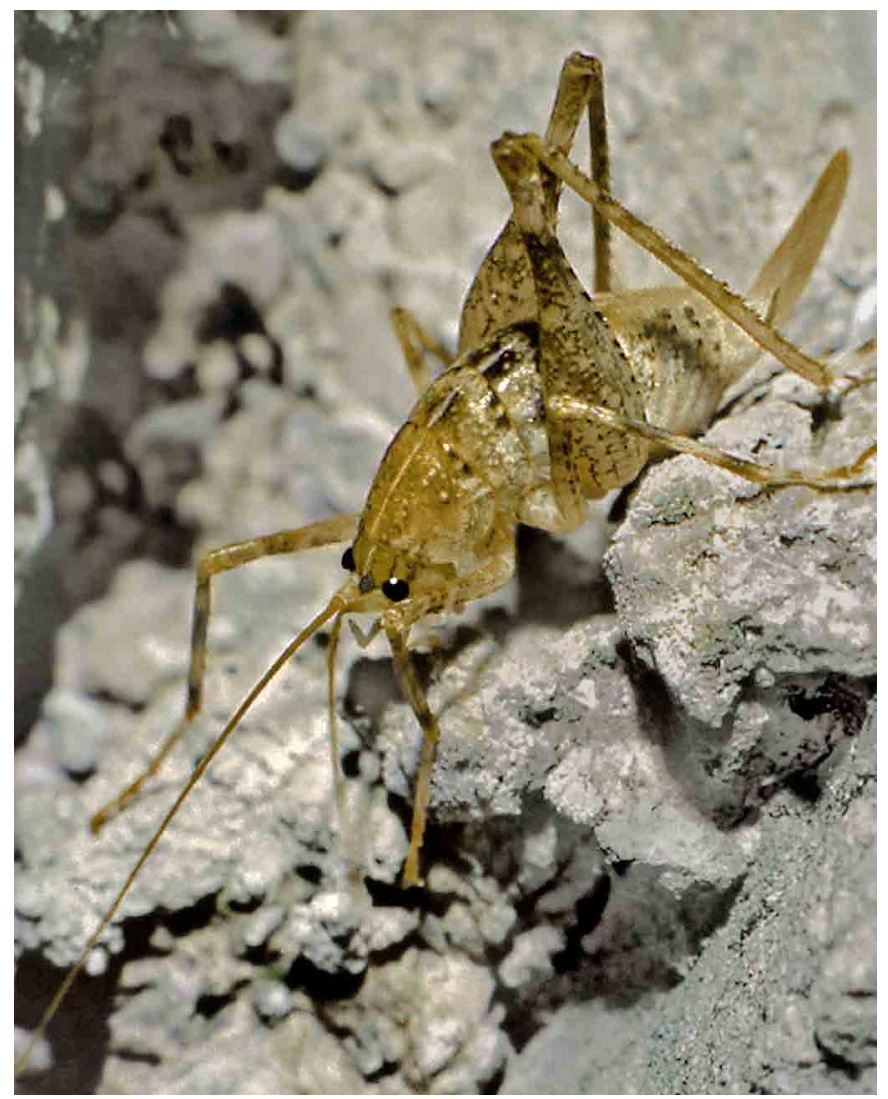

Fig. 15. Troglophilus cavicola. A female of the first orthopteran species described literally as "Höhlenheuschrecke" (cave cricket), at the type locality, the Schelmenloch south of Vienna. Photo J. Wurzenberger.

neglectus Krauss 1879 are restricted to Carinthia and Styria. Several ethological aspects of $T$. cavicola were investigated at the University of Graz (Kastberger, 1982, 1984, 1985, 1990; Kastberger \& Kropf, 1991; Kastberger \& Stabentheiner, 1989).

\section{Coleoptera}

Some tendency towards troglophily is observed in the trechine carabids Trechus austriacus Dejean 1831 and Trechoblemus micros (Herbst 1784). Although the blind Duvalius meixneri Kreiss1 1993 has been reported from only three caves west of Graz, morphological characters of the species indicate rather a dweller of deep soil and MSS habitats. Austrian representatives of the genera Orotrechus (two species), Anophthalmus (seven species-group taxa) and Aphaenopidius (one species), consistently blind and mostly troglobiont (Tab. 1), are limited to the Southern Calcareous Alps, mainly to the area south of River Drau (see the range of Anophthalmus in Fig. 8). In contrast, there is only one genus of blind, troglobiont Carabidae in the NCA, namely Arctaphaenops (Fig.8). Ten nominal species have been described, but a revision based on abundant material (Daffner, 1993) reduced the number of accepted species to three, plus one subspecies. A. angulipennis is distributed over the (relatively) largest area, with ssp. angulipennis (Meixner 1925) (Fig. 6) occurring in the region of Dachstein and Totes Gebirge and ssp. styriacus Winkler 1933 in the easternmost part of the Arctaphaenops range on both sides of the border between Styria and Lower Austria. A. gaisbergeri Fischhuber 1983 has been
Table 1. Blind beetles in subterranean habitats of Austria. $[\mathrm{N}]=$ Northern Calcareous Alps, $[\mathrm{C}]=$ Central Styria west of Graz, [S] = Southern Calcareous Alps. Data extracted from Daffner (1985, 1990, 1992); Drovenik et al. (2007); Fischhuber (1983); Kreissl (1993); Paill \& Kahlen (2009); Schmid $(1972,1974)$. The taxa have been recorded in caves or mining galleries, but those marked * rather inhabit rock crevices and MSS sites or supposably do so.

\begin{tabular}{|c|}
\hline Carabidae - Trechini \\
\hline${ }^{*}$ Duvalius meixneri Kreissl 1993 [C] \\
\hline Orotrechus carinthiacus Mandl 1940 [S] \\
\hline Orotrechus haraldi Daffner 1990 [S] \\
\hline $\begin{array}{l}\text { Arctaphaenops angulipennis angulipennis (Meixner 1925) (Syn.: } \\
\text { A. nihilumalbi Schmid 1972; A. putzi Fischhuber 1986; A. celinae } \\
\text { Genest 1991) [N] }\end{array}$ \\
\hline $\begin{array}{l}\text { Arctaphaenops angulipennis styriacus Winkler } 1933 \text { (Syn.: A. } \\
\text { ilmingi Schmid 1966; A. hartmannorum Schmid 1972) [N] }\end{array}$ \\
\hline Arctaphaenops gaisbergeri Fischhuber 1983 [N] \\
\hline $\begin{array}{l}\text { Arctaphaenops muellneri Schmid } 1972 \text { (Syn.: A. helgae Schmid } \\
\text { 1975) [N] }\end{array}$ \\
\hline * Anophthalmus bernhaueri bernhaueri (Ganglbauer 1895) [S] \\
\hline${ }^{*}$ Anophthalmus gobanzi gobanzi (Ganglbauer 1911) [S] \\
\hline${ }^{*}$ Anophthalmus gobanzi obirensis Jeannel 1928 [S] \\
\hline Anophthalmus haraldianus Daffner 1992 [S] \\
\hline $\begin{array}{l}\text { Anophthalmus pretneri fodinae Mandl } 1940 \text { (Syn.: A. ajdovskanus } \\
\text { fodinae auct.) [S] }\end{array}$ \\
\hline $\begin{array}{l}\text { Anophthalmus pretneri mixanigi Daffner } 1985 \text { (Syn.: A. } \\
\text { ajdovskanus mixanigi Daffner 1985) [S] }\end{array}$ \\
\hline $\begin{array}{l}\text { Anophthalmus schatzmayri Moravec \& Lompe } 2003 \text { (= A. mariae } \\
\text { auct.) [S] }\end{array}$ \\
\hline $\begin{array}{l}\text { Aphaenopidius kamnikensis Drovenik } 1987 \text { (nec A. treulandi auct.) } \\
\text { [S] }\end{array}$ \\
\hline Leiodidae - Leptodirini \\
\hline $\begin{array}{l}\text { *Aphaobius milleri brevicornis Mandl } 1940 \text { [S] - validity of the ssp. } \\
\text { questionable }\end{array}$ \\
\hline${ }^{*}$ Aphaobius milleri winkleri Mandl 1944 [S] \\
\hline $\begin{array}{l}{ }^{*} \text { Aphaobius milleri hoelzeli Mandl } 1957 \text { [S] - validity of the ssp. } \\
\text { questionable }\end{array}$ \\
\hline${ }^{*}$ Lotharia angulicollis Mandl 1944 [S] \\
\hline
\end{tabular}

recorded in three caves from the Traunstein to the Schafberg, thus marking the western limit of the genus range. A. muellneri Schmid 1972 is endemic to the Sengsengebirge and the Reichraminger Hintergebirge (Paill \& Kahlen, 2009).

The microphthalmic and distinctly eutroglophilic pterostichine carabid Laemostenus schreibersii (Küster 1846) occurs in Craoatia, Slovenia, northern Italy, southern Carinthia and Styria. Its subspecies carinthiacus Müller 1916 from Eggerloch (Villach) and styriacus Schmid 1970 from the Grazer Bergland have been synonymised with the nominate form. Rusdea (1992, 1994, 1998, 1999) investigated the population dynamics and the activity pattern of the Eggerloch population.

Eutroglophilic (partly guanophilic) staphylinid species such as Omalium validum Kraatz 1857, Atheta spelaea (Erichson 1840) and Quedius mesomelinus (Marsham 1802), and the leiodids Choleva bicolor Jeannel 1923, C. glauca Britten 1918 and Catops 
longulus Kellner 1846 were reported from Austrian caves.

Blind Leiodidae occur in caves and mining galleries of the Southern Calcareous Alps (Tab. 1). They belong to the Bathysciina and exhibit insignificant troglomorphy. The principal habitat of Lotharia angulicollis Mandl 1944, known solely from the type locality Hochobir, and Aphaobius milleri (Schmidt 1855), represented by the ssp. winkleri Mandl 1944 and two subspecies of doubtful validity, is probably the MSS.

\section{Hymenoptera}

Ichneumonids of the genus Diphyus are frequently found wedged in small cavities in the cave entrance region. The most common species is Diphyus quadripunctorius (Müller 1776).

\section{Trichoptera}

Adult caddisflies which more or less regularly undergo summer diapause in caves (Malicky \& Winkler, 1974) are Micropterna nycterobia McLachlan 1875, Mesophylax impunctatus McLachlan 1884, Stenophylax permistus McLachlan 1895 and S. vibex (Curtis 1834).

\section{Lepidoptera}

All the common Central European subtroglophilic moths and butterflies invade Austrian caves for diapause or hibernation, with Scoliotperyx libatrix (L.) and Triphosa dubitata (L.) being by far the most widespread. Notable is the winter sojourn of the acrolepiid moth Digitivalva pulicariae (Klimesch 1956) in caves of the easternmost karst region of Austria (Christian \& Moog, 1982).

\section{Diptera}

Subtroglophilic and eutroglophilic representatives of various dipteran families occur regularly in Austrian caves. Common species include Chionea austriaca (Christian 1980) and Limonia nubeculosa Meigen 1804 (Limoniidae); Trichocera hiemalis (De Geer 1776), T. maculipennis Meigen 1818 and $T$. regelationis (L.) (Trichoceridae); Culex pipiens (L.) (Culicidae); Bradysia forficulata (Bezzi 1914) (Sciaridae); Triphleba aptina (Schiner 1853) and T. antricola (Schmitz 1918) (Phoridae); Eristalis tenax (L.) (Syrphidae); Heleomyza modesta (Meigen 1835), H. serrata (L.) and Scoliocentra villosa (Meigen 1830) (Heleomyzidae). Two new taxa of Spaeroceridae were recently described from the highalpine Obstanser Eishöhle (2320 m a.s.1.), an icebearing cave in East Tyrol, namely the eutroglophilic subspecies Crumomyia cavernicola oculea Roháček \& Papp 2000 and the possibly troglobiont Crumomyia microps Roháček \& Papp 2000. Empty puparia of the bat-parasitic Nycteribiidae are occasionally found on cave walls.

\section{Biogeographic remarks}

The small Austrian portion of the Southern Calcareous Alps exhibits a higher biodiversity of air-breathing subterranean animals than the rest of the country. In Fig. 8 this region is represented for the most part by the range of Anophthalmus ground beetles. The biogeographic borderline passes the courses of the rivers Gail and Drau only at Villach where the Villacher Alpe harbors a southern toned cave fauna with, e.g., Anophthalmus schatzmayri. North of this line also the numbers of slowly dispersing soil arthropods decrease suddenly.

In contrast to this strip of high underground biodiversity, the Central Alps are extremely poor in terrestrial obligatory cave dwellers. This is not only due to the paucity of suitable habitats there. If ancient troglobionts had ever existed in the Central Alps, they were wiped out by the Würmian glaciers at the latest. Evidence supports the view that Pleistocene glacial periods decimated the fauna of the NCA less drastically. Cavernicolous taxa endemic to the NCA - those mapped in Fig. 8 and several others display highest biodiversity, both in terms of species numbers and distinctiveness, in the eastern part of the NCA between the rivers Salzach and Traisen. This area largely overlaps with the region of highest overall density of endemic plant and animal species in Austria (Rabitsch \& Ess1, 2009).

Single subterranean species have obviously survived at least the Würmian glaciation within or near their current ranges in the NCA, best indicated by the strikingly troglomorphic pseudoscorpion Neobisium aueri (Figs. 8, 9). Holocene immigration from the south, across the main ridges of the Alps, appears unlikely for such arthropods with restricted means of dispersion. This raises the question as to the shelters where endemics of the NCA caves may have endured the last glaciation. Christian (2002) compared current distribution patterns of cavernicolous Collembola in Austria and inferred four types of Quaternary range formation: (i) Holocene range expansion into formerly ice-covered regions; persistence (ii) in periglacial refugia (massifs de refuge) or (iii) in underground shelters at the borders of the the ice shield, without Holocene range expansion deep into formerly ice-covered regions; and (iv) survival on ice-free peaks and precipices (nunataks) amidst the continuous ice cover. Generally, the first scenario should apply to subtroglophilic and eutroglophilic species, whereas Holocene long-distance range expansion of troglobionts remains doubtful. The current distribution of the collembolan Cribrochiurus cribrosus, indicating survival on nunataks, is paralled by no other cave-dwelling species in Austria (Fig. 14).

Several species regularly occur in surface habitats of the alpine zone and become increasingly troglophilic at lower elevations. The woodlouse Mesoniscus alpicola and the springtail Isotomurus alticolus are examples for this height dependent change of the preferential habitat, termed refugiocaval distribution by Janetschek (1952). The temperature rise at the onset of the Holocene enabled such cold-adapted hygrophilic species to (re)conquer inner Alpine mountains, but drove them into subterranean shelters in the lowland. 


\section{ACKNOWLEDGEMENTS}

EC is deeply indebted to Dr. Fabio Stoch, Trieste, for the communication of references and unpublished data and valuable additions to the section on the aquatic fauna. We are grateful to P. Audra, P. Häuselmann, F. Stoch and an anonymous referee for their comments.

\section{REFERENCES}

Audra P., 2004 - Kitzsteinhorn high-alpine karst (Salzburg, Austria): evidence of non-glacial speleogenesis. Die Höhle, 55: 12-18.

Audra P., Bini A., Gabrovsek F., Häuselmann P., Hoblea F., Jeannin P.-Y., Kunaver J., Monbaron M., Sustersic F., Tognini P., Trimmel H. \& Wildberger A., 2007 Cave and karst evolution in the Alps and their relation to paleoclimate and paleotopography. Acta Carsologica, 36: 53-67.

Audra P., Quinif Y. \& Rochette P., 2002 - The genesis of the Tennengebirge karst and caves (Salzburg, Austria). J. Cave Karst Studies, 64: 153-164.

Bauer F., 1969 - Karsthydrologische Untersuchungen im Schneealpenstollen in den steirischniederösterreichischen Kalkalpen. Steir. Beitr. Hydrogeol., 21: 193-214.

Bauer F. \& Zötl J., 1972 - Karst of Austria. In: Herak M. \& Stringfield V.T. (Eds.) - Karst. Important Karst Regions of the Northern Hemisphere. Amsterdam: Elsevier: 225265.

Behrens H., Benischke R., Bricelj M., Harum T., Käss W., Kosi G., Leditzky H.P., Leibundgut C., Maloszewski P., Maurin V., Rajner V., Rank D., Reichert B., Stadler H., Stichler W., Trimborn P., Zojer H. \& Zupan M., 1992 Investigations with natural and artificial tracers in the karst aquifer of the Lurbach system (Peggau-TannebenSemriach, Austria). Steir. Beitr. Hydrogeol., 43: 9-158.

Beier M., 1962 - Ein Höhlen-Pseudoskorpion aus den Nördlichen Kalkalpen. Die Höhle, 13: 1-3.

Boch R, Spötl C. \& Kramers J., 2006 - Altersbestimmungen an zwei großen Stalagmiten der Grasslhöhle (2833/60). Die Höhle, 57: 63-65.

Breuss W., 2001 - Bemerkenswerte Spinnen aus Vorarlberg (Österreich) - I (Arachnida: Araneae: Lycosidae, Theridiidae, Mysmenidae, Gnaphosidae, Salticidae). Ber. nat.-med. Verein Innsbruck, 88: 183193.

Breuss W., 2004 - Bemerkungen zur Wibellosenfauna von Höhlen Vorarlbergs und angrenzender Gebiete. Vorarlberger Naturtschau, 15: 127-138.

Bruckner A., 1997 - Die Hornmilbenfauna der Hermannshöhle (Acarina; Oribatida). In: Hartmann H., Hartmann W. \& Mrkos H. (Eds.) - Die Hermannshöhle in Niederösterreich. Die Höhle, Wissensch. Beihefte, 50: $228-232$.

Christian E., 1980 - Eine neue Schneefliege aus der Chionea-Verwandtschaft: Niphadobata austriaca n. sp. (Dipt.: Tipulidae). Z. Arbeitsgem. Österr. Ent., 32: 7779.

Christian E., 1985 - Zur Collembolenfauna eines Permafrostbodens in der Karawanken-Nordkette. Carinthia II, 175/95: 141-149.
Christian E., 1986 - Onychiurus (Oligaphorura) hackeri n. sp., ein cavernicoler Springschwanz aus Niederösterreich (Hexapoda: Collembola). Ann. Naturhist. Mus. Wien, 87/B: $177-180$.

Christian E., 1987 - Composition and origin of underground arthropod fauna in an extrazonal permafrost soil of central Europe. Biol. Fert. Soils, 3: 27-30.

Christian E., 1993 - Collembolen aus zwei Windröhren des Ötscherlandes (Niederösterreich). Verh. Zool.-Bot. Ges. Österreich, 130: 157-169.

Christian E., 1997 - Die wirbellosen Tiere der Hermannshöhle bei Kirchberg am Wechsel, Niederösterreich. In: Hartmann, H., Hartmann, W. \& Mrkos, H. (Eds.) - Die Hermannshöhle in Niederösterreich. Die Höhle, Wissensch. Beihefte, 50: 205-224.

Christian E., 1998 a - Die Fauna der Katakomben des Wiener Stephansdomes. Verh. Zool.-Bot. Ges. Österreich, 135: 41-60.

Christian E., 1998 b - Megalothorax sanctistephani sp. $n$. from the catacombs of St. Stephen's Cathedral, Vienna (Collembola: Neelida). Ann. Naturhist. Mus. Wien, 100B: $15-18$.

Christian E., 1998 c - Eukoenenia austriaca from the catacombs of St. Stephen's Cathedral in the centre of Vienna and the distribution of palpigrades in Austria (Arachnida: Palpigradida: Eukoeneniidae). Senckenbergiana biol., 77: 241-245.

Christian E., 2002 - Distribution patterns of cavernicolous Collembola in Austria. Pedobiologia, 46: 261-266.

Christian E., 2004 a - Österreichische Höhlenentomologie im zwanzigsten Jahrhundert. Denisia, 13: 351-357.

Christian E., 2004 b - Palpigraden (Tasterläufer) Spinnentiere in einer Welt ohne Licht. In: Thaler K. (Ed.) - Diversität und Biologie von Webspinnen, Skorpionen und anderen Spinnentieren. Denisia, 12: 473-483.

Christian E., 2008 a - Arachnida: Palpigradi. Checklisten der Fauna Österreichs, No. 3. Wien: Österreichische Akademie der Wissenschaften: 2730.

Christian E., 2008 b - Höhlenheuschrecken - Zum Jubiläum einer Wortschöpfung. Die Höhle, 59: 48-58.

Christian E., Graf W. \& Moog O., 1996 - Plusiocampa caprai-Ein "Höhlentier" in den Kärntner Zentralalpen. Carinthia II, 186/106: 387-392.

Christian E. \& Moog O.,1982 - Zur Frage der ökologischen Klassifikation der Cavernicolen am Beispiel der Höhlen-Schmetterlinge Österreichs. Zool. Anz., 208: 382-392.

Christian E., Pospisil P. \& Haase M., 1994 - Autriche. In: Juberthie C. \& Decu V. (Eds.) - Encyclopaedia Biospeologica, vol. 1. Moulis and Bucarest: Société de Biospéologie: 595-603.

Clemens T., Jantschke H. \& Schäffler M., 1995 - Zur Herkunft der Eisen-Mangan-Erze in Höhlensedimenten der Horizontalhöhlen in der Reiteralm (Berchtesgadener Alpen). Die Höhle, 46: 66-74.

Daffner H., 1985 - Eine neue Rasse der Gattung Anophthalmus Sturm, 1844, aus Kärnten, Österreich. Entomofauna, 6: 361-370. 
Daffner H.,1990 - Orotrechus haraldi n. sp. aus Kärnten Austria (Coleoptera, Carabidae, Trechinae). Acta coleopt., 6: 51-60.

Daffner H., 1992 - Anophthalmus bernhaueri broderi ssp. n. aus Slovenien und Anophthalmus ajdovskanus haraldianus ssp. n. aus Kärnten (Coleoptera, Carabidae, Trechinae). Nachrichtenbl. bayer. Entomol., 41: 37-45.

Daffner H., 1993 - Die Arten der Gattung Arctaphaenops Meixner, 1925 (Coleoptera: Carabidae). Koleopt. Rundschau, 63: 1-18.

Danielopol D.L., 2001 - Groundwater ecology in Austria: origins and present-day achievements. In: Griebler C., Danielopol D.L., Gibert J., Nachtnebel H.P. \& Notenboom J. (Eds.) - Groundwater ecology. A tool for management of water resources. Luxembourg: European Communities: 31-37.

Danielopol D.L. \& Pospisil P., 2001 - Hidden biodiversity in the groundwater of the Danube Flood Plain National Park (Austria). Biodiversity and Conservation, 10: 1711-1721.

Danielopol D.L., Pospisil P., Dreher J., Mösslacher F., Torreiter P., Geiger-Kaiser M. \& Gunatilaka A., 2000 - A groundwater ecosystem in the wetlands of the Danube at Vienna (Austria). In: Wilkens H., Culver D. \& Humphreys W. (Eds.) - Caves and other subterranean ecosystems. Amsterdam: Elsevier: Ecosystems of the world 30: 487517.

Deharveng L., 1987 - Collemboles cavernicoles VI. Une nouvelle espèce souterraine de Neanurinae: Deutonura mirabilis n. sp. d'Autriche. Bull. Soc. ent. Fr., 91: 209-211.

Deharveng L. \& Christian E., 1984 - Gnathofolsomia palpata n. g., n. sp., eine Isotomide mit abgewandelten Mundwerkzeugen aus österreichischen Höhlen (Insecta, Collembola). Verh. Zool.-Bot. Ges. Österreich, 122: 97101.

Denneborg M., 2001 - Der Einfluss regionaler Grundwasserfließsysteme auf die Initialphase der Speläogenese tiefer Karstsysteme. Unpublished. $\mathrm{PhD}$ thesis Technical University Achen, 133 p.

De Waele J., Plan L., Audra P., Rossi A., Spötl C., Polyak V., Mcintosh W, 2009 - Kraushöhle (Austria): Morphology and mineralogy of an alpine sulfuric acid cave. Proc. $15^{\text {th }}$ Intern. Congr. Speleol., Kerrville, Texas, 2: 831-837.

Drovenik B., Weber F., Paill W. \& Assmann T., 2007 Aphaenopidius kamnikensis Drovenik, 1987 in Kärnten. Angewandte Carabidologie, 8: 73-76.

Eder R., 1979 - Zur Nematodenfauna der Hermannshöhle bei Kirchberg am Wechsel. Die Höhle, 30: 73-75.

Fischer K., 1990 - Höhlenniveaus und Altreliefgeneration in den Berchtesgadener Alpen. Mitt. Geogr. Ges. München, 75: 47-59.

Fischer W., 1997 - Checklist of Austrian Mollusca. http://ipp. boku.ac.at/private/wf/Check_List_of_Austrian_Mollusca. html (accessed 11 Nov. 2009)

Fischhuber M., 1983 - Arctaphaenops gaisbergeri n. sp., ein neuer Höhlenkäfer aus Oberösterreich (Col., Trechinae). Die Höhle, 34: 105-108.

Fišer C., Coleman C.O., Zagmajster M., Zwittnig B., Gerecke R. \& Sket B., in press - Old museum samples and recent taxonomy: A taxonomic, biogeographic and conservation perspective of the Niphargus tatrensis species complex (Crustacea: Amphipoda). Organisms Diversity and Evolution.
Frisch W., Kuhlemann J., Dunkl I. \& Székely B., 2008 Die geomorphologische Entwicklung der Ostalpen. Mitt. Österr. Geogr. Ges., 150: 123-162.

Frisch W., Kuhlemann J., Dunkl I. \& Székely B., 2001 - The Dachstein paleosurface and the Augenstein Formation in the Northern Calcareous Alps - a mosaic stone in the geomorphological evolution of the Eastern Alps. Int. J. Earth Sciences, 90: 500-518.

Frisch W., Székely B., Kuhlemann J. \& Dunkl I., 2000 - Geomorphological evolution of the Eastern Alps in response to Miocene tectonics. Z. Geomorph., 44: 103138.

Fritsch E., 1998 - Die Höhlenfauna des Hirlatzmassivs. In: Buchegger G. \& Greger W. (Eds.) - Die Hirlatzhöhle im Dachstein. Hallstatt: ARGE Hirlatzhöhlenbuch: 136-176.

Gaisberger K., 1984 - Katalog der rezenten Höhlentiere (Wirbellose) des Toten Gebirges. Bad Aussee: Heimatmuseum: 30 p.

Gaviria S., 1998 - Checklist and distribution of the freeliving copepods (Arthropoda: Crustacea) from Austria. Ann. Naturhist. Mus. Wien, 100B: 539-594.

Gaviria S. \& Pospisil P., 2009 - Aquatische Crustacea. In: Rabitsch W. \& Essl F. (Eds.) - Endemiten Kostbarkeiten in Österreichs Pflanzen- und Tierwelt. Klagenfurt \& Wien: Naturwiss. Verein für Kärnten \& Umweltbundesamt: 386-398.

Gerecke R., 2009 - Quellprojekt Nationalpark Gesäuse - 2. Quellwoche 2008. Bericht im Auftrag der NP Gesäuse $\mathrm{GmbH}$, Weng im Gesäuse, $11 \mathrm{p}$.

Gruber J., 2009 - Diplopoda (Doppelfüßer). In: Rabitsch W. \& Essl F. (Eds.) - Endemiten - Kostbarkeiten in Österreichs Pflanzen- und Tierwelt. Klagenfurt \& Wien: Naturwiss. Verein für Kärnten \& Umweltbundesamt: 512-541.

Haase M., 1992 - A new, stygobitic, valvatiform, hydrobiid gastropod from Austria (Caenogastropoda: Hydrobiidae). J. Moll. Stud., 58: 207-214.

Haase M., 1993 a - Belgrandiella ganslmayri, a new hydrobiid species from Upper Austria (Caenogastropoda). Ann. Naturhist. Mus. Wien, 94/95B: 181-186.

Haase M., 1993 b - Hauffenia kerschneri (Zimmermann 1930): zwei Arten zweier Gattungen. Arch. Moll., 121: 91-109.

Haase M., 1994 - Differentiation of selected species of Belgrandiella and the redefined genus Graziana (Gastropoda: Hydrobiidae). Zool. J. Linn. Soc., 111: 219-246.

Haase M., 1995 - The stygobitic genus Bythiospeum in Austria: a basic revision and anatomical description of $B$. cf. geyeri from Vienna (Caenogastropoda: Hydrobiidae). American Malacol. Bull., 11: 123-137.

Haase M., 1996 - The radiation of spring snails of the genus Belgrandiella in Austria (Mollusca: Caenogastropoda: Hydrobiidae). Hydrobiologia, 319: 119-129.

Haase M. \& Mildner P., 1996 - Hydrobiidae (Gastropoda, Prosobranchia) Kärntens: Zur Verbreitung der Gattung Graziana. Carinthia II, 186/106: 571-574.

Haase M., Weigand E. \& Haseke H., 2000 - Two new species of the family Hydrobiidae (Mollusca: Caenogastropoda) from Austria. The Veliger, 43: $179-189$. 
Haase M., Wilke T. \& Mildner P., 2007 - Identifying species of Bythinella (Caenogastropoda: Rissooidea): A plea for an integrative approach. Zootaxa, 1563: 1-16.

Heller C., 1858 - Beiträge zur österreichischen GrottenFauna. Sitz.-ber. k. Akad. Wiss., math.-naturw. Cl., Wien, 26: 313-326.

Herlicska H. \& Lorbeer G., 1994 - Pilotprojekt „Karstwasser Dachstein“ Band 1: Karstwasserqualität. Wien: Umweltbundesamt Monographie, 41: 1-233.

Hill C.A., 1990 - Sulfuric acid speleogenesis of Carlsbad Cavern and its relationship to hydrocarbons, Delaware Basin, New Mexico and Texas. Amer. Ass. Petrol. Geol. Bull., 74: 1685-1694.

Holdhaus K., 1906 - Über die Verbreitung der Koleopteren in den mitteleuropäischen Hochgebirgen. Verh. Zool.Bot. Ges. Wien, 56: 629-639.

Horninger G., 1959 - Baugeologisches vom Salzach-Kraftwerk Schwarzach. Österr. Z. Elektrizitätswirtschaft, 12: 48-50.

Janetschek H., 1952 - Beitrag zur Kenntnis der Höhlentierwelt der Nördlichen Kalkalpen. Jb. Ver. Schutz Alpenpflanzen u. -Tiere, München, 17: 69-92.

Juberthie C., Delay B. \& Bouillon M., 1980 - Sur l'existence d'un milieu souterrain superficiel en zone non calcaire. C. R. Acad. Sci., 290: 49-52.

Karaman G.S., 1991 - Some new interesting Gammaridean species from Austria and adjacent regions (Contributions to the knowledge of the Amphipoda 206). Glasn. Republ. Zavoda Zast. Prir. Muz. Podgorica, 24: 29-39.

Karaman G.S., 1992 - New data on genus Niphargus Schiodte, 1849 (Fam. Niphargidae) in Austria. Montenegrin Academy of Sciences and Arts, Glasnik of the Section of Natural Sciences, 8/9: 73-93.

Karaman G.S., 1994 - Further studies on genus Niphargus Schiödte from Europe, N. ivokaramani, $n$. $s p$., and N. danielopoli, n. sp. (Contributions to the knowledge of the Amphipoda 212). Glasn. Odjel. Prir. Nauka CANU, 10: 113-133.

Karaman S., 1955. - Asellus cavaticus Schioedte und seine Nächstverwandten. Acta Mus. Macedon. Sci. Nat., 2: 1-37.

Karg W., 1986 - Eine neue Raubmilbenart der Gattung Amblyseius Berlese, 1904 (Acarina, Parasitiformes, Phytoseiidae). Dtsch. ent. Z., n. s., 33: 223-226.

Kastberger G., 1982 - Evasive behaviour in the cavecricket, Troglophilus cavicola. Physiol. Entomol., 7: 175-181.

Kastberger G., 1984 - Gating of locomotor activity in the cave-cricket, Troglophilus cavicola. Physiol. Entomol., 9: 297-314.

Kastberger G., 1985 - Gating of ventilatory activity in the cave-cricket, Troglophilus cavicola. Physiol. Entomol., 10: 407-419.

Kastberger G., 1990 - Das Verhalten der Höhlenheuschrecke Troglophilus cavicola (Kollar) während der Imaginal-Häutung. Mitt. naturwiss. Ver. Steiermark, 120: 425-431.

Kastberger G. \& Kropf C., 1991 - Freilandbeobachtungen zur Spermatophoren-Übertragung bei der Höhlenschrecke Troglophilus cavicola (Kollar). Mitt. naturwiss. Ver. Steiermark, 121: 219-226.
Kastberger G. \& Stabentheiner A., 1991 - Präsoziale Gruppenbildungen bei der Höhlenschrecke Troglophilus cavicola. Mitt. naturwiss. Ver. Steiermark, 119: 129-135.

Kenk R., 1974 - Index of the genera and species of the freshwater triclads (Turbellaria) of the world. Smithson. Contrib. Zool., 183: 1-90.

Kollar V., 1833 - Systematisches Verzeichniss der im Erzherzogthume Oesterreich vorkommenden geradflügeligen Insekten. Beiträge zur Landeskunde Oesterreichs unter der Enns, 3/2: 67-87.

Komposch C. \& Gruber J., 2004 - Die Weberknechte Österreichs (Arachnida, Opiliones). In: Thaler K. (Ed.) - Diversität und Biologie von Webspinnen, Skorpionen und anderen Spinnentieren. Denisia, 12: 485-534.

Kralik M., 2001 - Strategie zum Schutz der Karstwassergebiete in Österreich. Wien: Umweltbundesamt Bericht, 198: 1-97.

Kralik M., Zieritz I., Grath J., Vincze G., Philippitsch R. \& Pavlik H., 2005 - Hydrochemische Karte Österreichs. Wien: Umweltbundesamt Bericht, 269: 1-17.

Kraus F., 1894 - Höhlenkunde. Wege und Zweck der Erforschung unterirdischer Räume. Mit Berücksichtigung der geographischen, geologischen, physikalischen, anthropologischen und technischen Verhältnisse. Gerold, Wien, 308 p. (Annotated reprint 2009: Die Höhle, Wiss. Beiheft 56, 336 p.)

Kreissl E., 1993 - Duvalius meixneri spec. nov. - ein neuer Höhlenkäfer aus der Steiermark. Mitt. Abt. Zool. Landesmus. Joanneum, 47: 103-108.

Krenmayr H.G., 2002 - Rocky Austria. Eine bunte Erdgeschichte von Österreich. $2^{\text {nd }}$ ed., Wien: Geol. Bundesanstalt, $63 \mathrm{p}$.

Kuhlemann J., Taubald H., Vennemann T., Dunkl I. \& Frisch W, 2008 - Clay mineral and geochemical composition of Cenozoic paleosol in the Eastern Alps (Austria). Austrian J. Earth Sci., 101: 60-69.

Lauritzen S.E., 2001 - Marble stripe karst of the Scandinavian Caledonides: an end-member in the contact karst spectrum. Acta Carsologica, 30: 47-79.

Maier H.C. \& Gressel W., 1977 - Zur Höhlenfauna im Eisenkappel-Seeberg-Gebiet (Südostkärnten). Carinthia II, 167/87: 367-384.

Mais K., 1969 - Zur Kenntnis der ökologischen Valenz von Onychiurus cavernicolus und $O$. vornatscheri (Collembola, Insecta apterygota). Über Temperatur-, Feuchtigkeits- und Lichtreaktionen. Pedobiologia, 9: 282-287.

Malicky H. \& Winkler G., 1974 - Untersuchungen über die Höhlenimmigration von Micropterna nycterobia (Trichoptera, Limnephilidae). Oecologia, 15: 375-382.

Mandl K., 1940 - Die Blindkäferfauna der Karawanken. Koleopt. Rundschau, 26: 25-36.

Mandl K., 1944 - Die Blindkäferfauna der Karawanken. II. Teil. Koleopt. Rundschau, 29: 103-108.

Mandl K., 1957 - Die Blindkäferfauna der Karawanken. III. Entomol. Nachr.-bl. Österr. Schweiz. Entomol., 9: 3-10.

Meixner J., 1925 - Trechus (Arctaphaenops nov. subgen.) angulipennis n. sp., ein Höhlenlaufkäfer aus dem Dachsteinmassiv. (Studien über die Gattung Trechus III). Koleopt. Rundschau, 11: 130-136. 
Meyer M.C., Cliff R.A., Spötl C., Knipping M. \& Mangini A., 2009 - Speleothems from the earliest Quaternary: snapshots of paleoclimate and landscape evolution at the northern rim of the Alps. Quat. Sci. Rev., 28: 1374-1391.

Moog O., 1982 - Die Verbreitung der Höhlenheuschrecken Troglophilus cavicola Kollar und T. neglectus Krauss in Österreich (Orthoptera, Rhaphidophoridae). Sitz.-ber. Österr. Akad. Wiss., math.-naturw. Kl., Abt. 1, 191: 185-207.

Neuherz H., $1974 \quad$ - Ökologisch-faunistische Untersuchungen über die Hydrofauna der Lurgrotte zwischen Peggau und Semriach in der Steiermark. Sitz.ber. Österr. Akad. Wiss., math.-naturw. Kl., Abt. 1, 182: 103-146.

Neuherz H., 1975 - Die Landfauna der Lurgrotte (Teil 1). Sitz.-ber. Österr. Akad. Wiss., math.-naturw. Kl., Abt. 1, 183: 159-285.

Neuherz H., 1979 - Onychiurus (Protaphorura) reisingeri sp. n. - eine neue Collembolenart aus der RaudnerHöhle (Kat. Nr. 2783/4), Steiermark. Mitt. naturwiss. Ver. Steiermark, 109: 317-322.

Neuherz H., 1984 - Torocampa hölzeli n. gen., n. spec. - eine neue klasobionte Campodeide (Diplura, Apterygota) aus der Hafnerhöhle in den Karawanken, Kärnten (Kat.-Nr. 3915/ 1). Carinthia II, 174/94: 415-427.

Nosek J. \& Christian E., 1983 - Onychiurus (Oligaphorura) pseudoraxensis n. sp. - Ein neuer Springschwanz (Hexapoda: Collembola) aus einer niederösterreichischen Höhle. Ann. Naturhist. Mus. Wien, 84/B: 397-400.

Paill W. \& Kahlen M., 2009 - Coleoptera (Käfer). In: Rabitsch W. \& Essl F. (Eds.) - Endemiten - Kostbarkeiten in Österreichs Pflanzen- und Tierwelt. Klagenfurt \& Wien: Naturwiss. Verein für Kärnten \& Umweltbundesamt: 627783.

Pavuza R., Mais K., 1999 - Aktuelle höhlenklimatische Aspekte der Dachstein-Rieseneishöhle. Die Höhle, 50: 126140.

Pesce G.L. \& Galassi D.P., 1994 - Elaphoidella plesai $n$. sp. from ground waters of Austria (Copepoda Harpacticoida: Canthocamptidae). Ann. Limnol., 30: 91-94.

Pfarr T., Plan L., Seebacher R. \& Stummer G., 2007 Österreichs längste und tiefste Höhlen. Die Höhle, 58: 112115.

Pfiffner A.O., 2009 - Geologie der Alpen. Haupt, Bern, 359 p.

Plan L., Pavuza R., Seemann R., 2006 - Der Nasse Schacht bei Mannersdorf am Leithagebirge, NÖ (2911/21) - eine thermal beeinflusste Höhle am Ostrand des Wiener Beckens. Die Höhle, 57: 30-46.

Plan L., Spötl C., Pavuza R. \& Dublyansky Y., 2009 a Hypogean caves in Austria. In: Klimchouk A. \& Ford D. (Eds.) - Hypogene Speleogenesis and Karst Hydrogeology of Artesian Basins. Ukrainian Institute of Speleology and Karstology, Spec. Paper 1: 121-127.

Plan L., Decker K., Faber R., Wagreich M. \& Grasemann B., 2009 b - Karst morphology and groundwater vulnerability of high alpine karst plateaus. Environm. Geol., 58: 285297.

Pospisil P., 1989 - Acanthocyclops gmeineri n. sp. (Copepoda, Cyclopoida) aus dem Grundwasser von Wien (Österreich). Bemerkungen zur Zoogeographie und zur Sauerstoffsituation des Grundwassers am Fundort. Zool. Anz., 223: 220-230.
Pospisil P., 1994 - The groundwater fauna of a Danube aquifer in the "Lobau" wetland in Vienna, Austria. In: Gibert J., Danielopol D.L. \& Stanford J.A. (Eds.) - Groundwater Ecology. San Diego: Academic Press: 346-366.

Pospisil P., 1999 - The composition of cyclopoid assemblages in ecologically different groundwater habitats of a Danube riverine wetland in Austria. Crustaceana, 72: 883-892.

Pospisil P. \& Stoch F., 1999 - Two new species of the Diacyclops languidoides-group (Crustacea, Copepoda, Cyclopoida) from groundwaters of the Danube plain, Austria. Hydrobiologia, 412: 165-176.

Puchelt H. \& Blum N., 1989 - Geochemische Aspekte der Bildung des Gipsvorkommens der Kraushöhle / Steiermark. Oberrhein. geol. Abh., 35: 87-99.

Rabitsch W. \& Essl F., 2009 - Verbreitungsmuster. In: Rabitsch W. \& Essl F. (Eds.) - Endemiten Kostbarkeiten in Österreichs Pflanzen- und Tierwelt. Klagenfurt \& Wien: Naturwiss. Verein für Kärnten \& Umweltbundesamt: 878-898.

Reischütz A. \& Reischütz P.L., 2009 - Mollusca (Weichtiere). In: Rabitsch W. \& Essl F. (Eds.) - Endemiten - Kostbarkeiten in Österreichs Pflanzen- und Tierwelt. Klagenfurt \& Wien: Naturwiss. Verein für Kärnten \& Umweltbundesamt: 318-376.

Rogulj B. \& Danielopol D.L., 1993 - Three new Mixtacandona (Ostracoda) species from Croatia, Austria and France. Vie et Milieu, 43: 145-154.

Roháček J. \& Papp L., 2000 - Crumomyia microps sp. n. from Austria and notes on other cavernicolous Crumomyia species (Diptera: Sphaeroceridae). Ann. hist.-nat. Mus. natn. hungarici, 92: 215-228.

Rusdea E., 1992 - Stabilisierende Selektion bei microphthalmen Höhlentieren: Untersuchungen zur tageszeitlichen Aktivitätsverteilung und Populationsdynamik von Laemostenus schreibersi Küster (Carabidae). Mém. Biospéol., 19: 1-110.

Rusdea E., 1994 - Population dynamics of Laemostenus schreibersi (Carabidae) in a cave in Carinthia (Austria). In: Desender K., Dufrere M., Loreau M., Luff M.L. \& Maufait J.P. (Eds.) - Carabid beetles: Ecology and Evolution. Ser. Entomol. 51. Dordrecht: Kluwer: 207212.

Rusdea E., 1998 - Stabilization of a Laemostenus schreibersi population (Coleoptera, Carabidae) as an effect of adult longevity - results of a long-term investigation over 10 years. In: Baumgärtner J., Brandmayr P. \& Manly B. (Eds.) - Population and Community Ecology for Insect Management and Conservation. Rotterdam / Brookfield: Balkema: 157-166.

Rusdea E., 1999 - Der höhlenbewohnende Laufkäfer Laemostenus schreibersi (Coleoptera, Carabidae) im Felsspaltensystem. In: Möseler B.M. \& Molenda R. (Eds.) - Lebensraum Blockhalde. Decheniana-Beihefte, 37: 127-140.

Ruzicka V. \& Thaler K., 2002 - Spiders (Araneae) from Deep Screes in the Northern Alps (Tyrol, Austria). Ber. nat.-med. Verein Innsbruck, 89: 137-141.

Saar R. v., 1956 - Eishöhlen, ein meteorologischgeophysikalisches Phänomen. Geografiska Annaler, 38: 1-63. 
Scheidleder A., Boroviczeny F., Graf W., Hofmann T., Mandl G.W., Schubert G., Stichler W., Trimborn P. \& Kralik M., 2001 - Pilotprojekt "Karstwasser Dachstein". Bd. 2: Karsthydrologie und Kontaminationsrisiko von Quellen. Wien: Umweltbundesamt Monographie, 108: 1-155.

Schiemer F., 1984 - Theristus franzbergeri n. sp., a groundwater nematode of marine origin from the Danube. Arch. Hydrobiol., 101: 259-263.

Schmid M. E., 1970 - Ein neuer Antisphodrus aus der Steiermark (Coleoptera, Carabidae). Die Höhle, 21: 4446.

Schmid M. E., 1972 - Weitere Arctaphaenops-Funde aus Oberösterreich (A. angulipennis Meixner, A. muellneri $n$. sp. - Col., Trechinae). Die Höhle, 23: 95-100.

Schmid M. E., 1974 - Die blinden Trechinae und Bathysciinae Österreichs (Col.: Carabidae, Catopidae). Acta entomol. Jugosl., 10: 157-160.

Schubert G., 2000 - Water resources - drinking water. Mitt. Österr. Geol. Ges., 92: 295-311.

Seemann R., 1979 - Die sedimentären Eisenvererzungen der Karstgebiete der Nördlichen Kalkalpen. Ann. Naturhist. Mus. Wien, 82: 209-290.

Serban E., 1989 - Taxa nouveaux des Bathynellidés d'Europe (Bathynellacea, Podophallocarida, Malacostraca). Trav. Inst. Spéol. „Ėmile Racovitza“, 28: 3-17.

Sillaber H., 1986 - Trachysphaera fabbrii (Verhoeff, 1929) in der Lurgrotte und am Ötscher (Myriapoda, Diplopoda). Mitt. Abt. Zool. Landesmus. Joanneum, 39: 17-21.

Spandl H., 1926 - Die Tierwelt der unterirdischen Gewässer. Wien: Speläol. Monogr., 11: 235 p.

Spötl C., Burns S.J., Frank N., Mangini A. \& Pavuza N., 2004 - Speleothems from the High-Alpine Spannagel Cave, Zillertal Alps (Austria). In: Sasowsky I.D. \& Mylroie J. (Eds.) - Studies of Cave Sediments. Physical and Chemical Records of Paleoclimate. Dordrecht: Kluwer: 243-256.

Spötl C., Offenbecher K.-H., Boch R., Meyer M., Mangini A., Kramers J. \& Pavuza R., 2007 - TropfsteinForschung in österreichischen Höhlen - ein Überblick. Festschrift H.-P. Schönlaub. Jb. Geol. Bundesanstalt, 147: 117-167.

Spötl C., Dublyansky Y., Meyer M. \& Mangini A., 2009 - Identifying low-temperature hydrothermal karst and palaeowaters using stable isotopes: a case study from an alpine cave, Entrische Kirche, Austria. Intern. J. Earth Sci., 98: 665-676.

Steininger F.F. \& Wessely G., 2000 - From the Tethyan Ocean to the Paratethys Sea: Oligocene to Neogene stratigraphy, paleogeography and paleobiology of the circum-Mediterranean region and the Oligocene to Neogene basin evolution in Austria. Mitt. Österr. Geol. Ges., 92: 95-116.

Stoch F., 2004 - Prime osservazioni sulla fauna delle acque carsiche sotteranee delle Alpi Carniche. Mem. Ist. It. Spel., s. 2, 15: 87-95.

Stoch F. \& Pospisil P., 2000 a - The Diacyclops languidoides - group (Copepoda: Cyclopoida) in Austria, with redescription of Diacyclops cohabitatus Monchenko, 1980. Annls. Limnol., 36: 21-29.
Stoch F. \& Pospisil P., 2000 b - Redescription of Diacyclops disjunctus (Thallwitz, 1927) from Austria, with remarks on the Diacyclops languidus - group in Europe (Copepoda, Cyclopoida, Cyclopidae). Crustaceana, 73: 469-478.

Stomp N., 1986 - Le groupe de Pseudosinella vandeli (Insectes, Collemboles) dans les Alpes Orientales. In: Dallai R. (Ed.) - Second International Seminar on Apterygota. Siena: Univ. of Siena: 85-91.

Stomp N. \& Tommasi-Ursone M.L., 1989 - A new species of Pseudosinella (Insecta, Collembola) from an Austrian cave. Bull. Soc. Nat. Luxemb., 89: 151-156.

Stomp N., Tommasi-Ursone M.L. \& Christian E., 1991 - Description et redescription de quelques espèces de Pseudosinella cavernicoles d'Autriche (Insectes, Collemboles). Bull. Soc. Nat. Luxemb., 92 : 121-130.

Straskraba M., 1972 - L'etat actuel de nos connaissances sur le genre Niphargus en Tchecoslovaquie et dans les pays voisins. Verona: Actes 1. Coll. intern. genre Niphargus: 35-46.

Strasser K., 1959 - Die Diplopoden (Tausendfüßler) von Kärnten. Carinthia II, 69: 58-84.

Strasser K., 1967 - Ein Typhloiuline aus den Nördlichen Kalkalpen (Diplopoda Symphyognatha). Ber. nat.-med. Ver. Innsbruck, 55: 145-154.

Strouhal H., 1939 - Die in den Höhlen von Warmbad Villach, Kärnten, festgestellten Tiere. Folia zool. hydrobiol., 9: 247-290.

Strouhal H., 1940 - Die Tierwelt der Höhlen von Warmbard Villach in Kärnten. Ein Beitrag zur Ökologie der Makrocavernen. Arch. Naturgesch., N.F., 9: 372434.

Strouhal H., 1958 a - Asellus (Proasellus) im nördlichen Österreich (Isopoda, Asellota). Ann. Naturhist. Mus. Wien, 62: 263-283.

Strouhal H., 1958 b - Neue südostalpine TrichoniscusArten aus Österreich (Isopoda, Oniscoidea). Ann. Naturhist. Mus. Wien, 62: 283-295.

Strouhal H. \& Vornatscher J. -1975 - Katalog der rezenten Höhlentiere Österreichs. Ann. Naturhist. Mus. Wien, 79: 401-542.

StummerA., 1984-EineneueUnterartderHöhlenschnecke Zospeum alpestre (Freyer) aus der Kupitzklamm bei Eisenkappel, Kärnten (Basommatophora: Ellobiidae). Heldia, 1: 13-14.

Thaler K., 1975 - Trogloneta granulum Simon, eine weitere Reliktart der Nordostalpen (Arachnida, Aranei, „Symphytognathidae"). Rev. suisse Zool., 82: 283291.

Thaler K., 1978 - Troglohyphantes novicordis n. sp. aus der Steiermark, Österreich (Arachnida: Araneae: Linyphiidae). Senckenbergiana biol., 59: 289-296.

Thaler K., 1999 - Troglohyphantes typhlonetiformis Absolon et Kratochvil - neu für Österreich (Arachnida, Araneae, Linyphiidae). Carinthia II, 189/109: 467469.

Thaler K. \& Neuherz H., 1978 - Über zwei HöhlenDiplopoden der Steiermark (Diplopoda, Chilognatha: Gervaisiidae und Attemsiidae). Mitt. Abt. Zool. Landesmus. Joanneum, 7: 31-38.

Thibaud J.-M. \& Christian E., 1997 - Biodiversity of interstitial Collembola (Insecta) in sand sediments. Eur. J. Soil Biol., 33: 123-127. 
Tilzer M., 1973 - Zum Problem der Ausbreitungsfähigkeit von limnisch-interstitiellen Grundwassertieren, am Beispiel von Troglochaetus beranecki Delachaux (Polychaeta, Archiannelida). Arch. Hydrobiol., 72: 263-269.

Veit H., 2002 - Die Alpen - Geoökologie und Landschaftsentwicklung. Ulmer, Stuttgart, 352 p.

Vornatscher J., 1943 - Zur Verbreitung von Plusiocampa strouhali Silv. Z. f. Karst- U. Höhlenkunde, 1942/1943: 174-178.

Vornatscher J., 1950 - Der erste Fund eines echten Höhlentieres nördlich der Drau. Die Höhle, 1: 6-8.

Vornatscher J., 1965 - Amphipoda. Catalogus Faunae Austriae, 8f: 1-3.

Wettstein-Westersheim O., 1926 - Zoologische Beobachtungen. - In: Angermayer E. (Ed) - Die Eisriesenwelt im Tennengebirge (Salzburg). Wien: Speläologische Monographien 6: 124-125.

Wichmann H.E., 1926 - Untersuchungen über die Fauna der Höhlen. II. Echte Höhlentiere in den Nordostalpen. Zool. Anz., 67: 250-252.

Wigley T.M.L. \& Brown M.C., 1976 - The physics of caves. In: Ford T.D. \& Cullingford C.H.D. (Eds.) - The Science of Speleology. London: Academic Press: $329-358$.

Wimmer M., 2008 - Eis-und Lufttemperaturmessungen im Schönberg-Höhlensystem (1626/300) und Modellvorstellungen über den Eiszyklus. Die Höhle, 59: 13-25.
Winkler A., 1933 - Eine zweite Höhlenlaufkäferart aus den Nordalpen: Arctaphaenops styriacus sp. n. Koleopt. Rundschau, 19: 237-240.

Zacharda M., 2000 a - New species of the rhagidiid genus Foveacheles (Acari: Prostigmata: Eupodoidea) with a lyrifissure-like structure on the chelicerae. J. Nat. Hist., 34: 247-265.

Zacharda M., 2000 b - New species of the genus Troglocheles (Acari: Prostigmata: Rhagidiidae) from Oetztal Alps, Tyrol, with a key to adult species of the genus. J. Nat. Hist., 34: 463-478.

Zacharda M., $2000 \mathrm{c}-$ New and little-known species of Rhagidiidae from talus ecosystems, in the Czech Republic and Austria. J. Zool. London, 251: 105118.

Zacharda M., $2000 \mathrm{~d}-A$ new species of the genus Evadorhagidia (Acari: Prostigmata: Rhagididae) from talus ecosystems, with a key to the world species of the genus. Acarologia, 40: 373-383.

Zacharda M.. 2001 - Talus formations - remarkable biotopes for acarological research, with examples from the Rhagidiidae (Acari: Prostigmata). In: Halliday R.B., Walter D.E., Proctor H.C., Norton R.A. \& Colloff M.J. (Eds.) - Acarology. Proc. 10 Int. Congr. Melbourne, CSIRO Publishing, 269271.

Zötl J. \& Goldbrunner J.E., 1993 - Die Mineral- und Heilwässer Österreichs. Geologische Grundlagen und Spurenelemente. Springer, Wien, 324 p. 